\title{
ACUERDOS PREMATRIMONIALES EN PREVISIÓN \\ DE RUPTURA MATRIMONIAL: EL TEST CONFLICTUAL Y MATERIAL A TENER EN CUENTA PARA QUE UN ACUERDO PREMATRIMONIAL SUPERE UNA REVISIÓN JUDICIAL ANTE TRIBUNALES ESPAÑOLES
}

\author{
PREMARITAL AGREEMENTS IN ANTICIPATION OF MARITAL \\ BREAKDOWN: THE CONFLICTUAL AND MATERIAL TEST TO \\ TAKE INTO ACCOUNT SO THAT A PRENUPTIAL AGREEMENT \\ PASSES A JUDICIAL REVIEW BEFORE SPANISH COURTS
}

\author{
ISABEL ANTÓN JUÁREZ \\ Profesora Ayudante Doctora de Derecho internacional privado \\ Universidad Carlos III de Madrid \\ ORCID ID: 0000-0002-5639-2301
}

Recibido: 15.01.2019 / Aceptado: 31.01.2019

DOI: https://doi.org/10.20318/cdt.2019.4615

\begin{abstract}
Resumen: Los acuerdos prematrimoniales internacionales en previsión de ruptura son acuerdos cada vez más utilizados. Sin embargo, su frecuencia no hace que sean acuerdos fáciles a la hora de su ejecución. Esta situación suele tener lugar porque tras la ruptura uno de los cónyuges no suele estar de acuerdo con lo establecido años atrás en el acuerdo prematrimonial. En el caso de que el peor escenario se plantee y sea necesario acudir a los tribunales, es importante tener en cuenta qué aspectos o requisitos son importantes para que el acuerdo supere una revisión judicial. Estos requisitos se van a plantear desde una doble vertiente: conflictual y material.
\end{abstract}

Palabras clave: acuerdo prematrimonial, divorcio, régimen económico matrimonial, ley aplicable.

\begin{abstract}
International prenuptial agreements in anticipation of rupture are increasingly used agreements. However, their frequency does not make them easy agreements at the time of their enforcement. This situation usually takes place because after the divorce one of the spouses does not usually agree with what was established years ago in the prenuptial agreement. In the event that the worst scenario arises and it is necessary to go to court, it is important to consider what aspects or requirements are important for the agreement to pass judicial review. These requirements will be raised from a double perspective: conflictual and material.
\end{abstract}

Keywords: prenuptial agreement, divorce, matrimonial property regime, aplicable law.

Sumario: I. Introducción. II. El concepto de acuerdo prematrimonial. II. La revisión de los acuerdos prematrimoniales ante jueces españoles: ¿Cómo elaborar un acuerdo prematrimonial eficaz a prueba de revisiones judiciales posteriores tanto desde una perspectiva conflictual como material?. 1. Aproximación inicial. 2. Requisito 1:la capacidad de las partes. A) La determinación de la Ley aplicable a la capacidad de las personas físicas. B) El derecho español como Ley aplicable a la capacidad. 3. Requisito 2: forma del acuerdo. A) Aspectos relativos a la Ley aplicable. B) Cuestiones materiales. 4. Requisito 3: el consentimiento. 5. Requisito 4. El contenido del acuerdo no puede da- 
ñar el orden público, la moral ni la ley. A) Determinación del Derecho aplicable al fondo del acuerdo prematrimonial. B) El contenido del acuerdo prematrimonial desde el Derecho material español: Límites generales a la autonomía de la voluntad: el orden público, la ley y la moral.6.Requisito 5: análisis de las circunstancias al momento de la ejecución. A) Alteración sobrevenida de las circunstancias y grave perjuicio. A) Acuerdos con especial transcendencia al momento de la ejecución del acuerdo: cláusulas en los que se renuncian a derechos futuros y pactos en los que se atribuye una prestación patrimonial no reconocida por la ley. a)La renuncia anticipada a la prestación compensatoria. b)la renuncia al uso de la vivienda familiar. c) la reciente sentencia del TS de 30 de mayo de 2018. d) Pactos en los que se atribuye una prestación patrimonial no exigida por la ley. c) Pactos indemnizatorios. IV. Consideraciones finales.

\section{Introducción}

1. Los acuerdos prematrimoniales donde se prevén los efectos de una posible ruptura son cada vez son más frecuentes en la actualidad. Los matrimonios mixtos, los matrimonios deslocalizados, las segundas y sucesivas nupcias, la concepción actual del matrimonio y el fácil acceso al divorcio, entre otras, son las razones que dan lugar que cada vez sea más habitual que jueces, abogados y notarios tengan que revisar o asesorar sobre este tipo de pactos.

2. El escenario del que partimos para elaborar el presente trabajo es el siguiente: un futuro matrimonio realiza un acuerdo antes del enlace, en él se renuncian a derechos, se recoge una indemnización en caso de infidelidad de alguno de ellos y se establece el régimen económico matrimonial. El problema aparece cuando surge la separación o el divorcio. Uno de ellos no está conforme con lo firmado, considerando que el pacto es nulo y que no puede desplegar efectos. En este caso, los cónyuges al no llegar a un consenso sobre posibles modificaciones al mismo, deciden acudir a la vía judicial para que sea un juez el que decida si ese acuerdo firmado años atrás puede desplegar efectos en el presente. Sin embargo, esta opción no tiene por qué tranquilizar a las personas a las que les afecta el acuerdo. Las cuales pueden ser no sólo cónyuges, también podrían ser sus hijos o sus acreedores. Esta intranquilidad es consecuencia de un interrogante y es si el acuerdo va a superar o no la revisión judicial.

Para que esa revisión se supere, ya que con ese fin en principio se supone que se firmó el acuerdo, consideramos que a la hora de prestar asesoramiento es necesario tener en cuenta las circunstancias de los cónyuges en las que se firmó el acuerdo y también las circunstancias en el momento de su revisión judicial. Pero legamente no podemos dejarlo todo en manos de las circunstancias. Así, consideramos que un asesoramiento de calidad debe tener como pilar la precisión jurídica. De este modo, con el fin dar un asesoramiento preciso tanto a la pareja que está pensando en firmar un prenup como a la que se ve envuelta en un proceso judicial para defenderlo o atacarlo es necesario tener en cuenta los requisitos o criterios que vamos a explicar a lo largo del presente estudio.

3. Este trabajo se aborda partiendo de la idea de que el acuerdo que es necesario revisar ante un juez es un acuerdo prematrimonial internacional. Un acuerdo, en el que por una razón u otra (nacionalidad de las partes, residencia habitual...), contiene un elemento extranjero. De hecho, si se analiza la jurisprudencia, es notorio que un alto porcentaje de los acuerdos prematrimoniales que llegan a los tribunales españoles presentan algún elemento extranjero. Prueba de ello es la última sentencia del Tribunal Supremo (en adelante, TS) sobre acuerdos prematrimoniales de mayo del año 2018 ${ }^{1}$. En ella se puede observar como el acuerdo prematrimonial se celebró entre rusa y español.

Por ese motivo, consideramos necesario incluir en el estudio un análisis internacional privatista de los acuerdos prematrimoniales. Para desarrollar este análisis es necesario precisar desde el inicio, que como ya defendimos en anteriores trabajos ${ }^{2}$, que nuestra visión es que en la medida de lo posible siempre que el ámbito de aplicación de la norma de conflicto sobre efectos del matrimonio lo permita

STS de 30 de mayo de 2018, nº 1925/2018, ECLI:ES:TS:2018:1925.

2 I. ANTÓN JuÁREZ, "Los acuerdos prematrimoniales en Derecho Internacional privado español”, Revista de estudios socio jurídicos, Bogotá (Colombia), enero 2019, pp. 68-77. 
sería deseable que la Ley aplicable para determinar la validez del acuerdo prematrimonial sea una única ley. La Ley del mismo ordenamiento jurídico. Somos conscientes de que hay doctrina que ha planteado una opinión opuesta. Estos autores han planteado que el fraccionamiento de ley es una opción viable para determinar el derecho aplicable al acuerdo prematrimonial ${ }^{3}$. Este argumento es lógico debido a las diferentes cláusulas sobre distintas materias que puede contener un acuerdo prematrimonial. Sin embargo, entendemos que siempre que se pueda aplicar una única ley, siendo ésta la ley que rige el régimen económico matrimonial, sería la opción más plausible desde un punto de vista práctico. Por esta tesis que sostenemos de unidad de ley, la norma de conflicto principal que se va a utilizar para determinar si un acuerdo es válido cuando tengamos que analizar la validez material va a ser el art. 9.3 CC o el Reglamento (UE) 2016/1103 del Consejo de 24 de junio de 2016 por el que se establece una cooperación reforzada en el ámbito de la competencia, la ley aplicable, el reconocimiento y la ejecución de resoluciones en materia de regímenes económicos matrimoniales (en adelante, RREM) 4

No obstante, somos conscientes de que en la actualidad, donde el Derecho internacional privado, es cada vez más europeo y, por tanto, menos nacional, esta postura de aplicar la misma ley a todo el acuerdo prematrimonial puede tener un difícil encaje cuando se trata de acuerdos que contienen cláusulas muy distintas entre sí. Cláusulas de diversa naturaleza jurídica (ad ex. se renuncia a la pensión compensatoria y al mismo tiempo se fijan medidas relativas al cuidado de los hijos), escapándose alguna de ellas del ámbito de aplicación del RREM. En ese caso, tendremos que ver de que cláusula concreta se trata y analizarla desde un punto de vista conflictual y también material. Esto podría dar lugar a que en el acuerdo se aplicaran leyes de dos ordenamientos diferentes. A nuestro juicio, el reto jurídico que plantea este escenario no es sólo por el hecho de que se apliquen varias leyes al acuerdo prematrimonial sino también por las calificaciones que desde el plano conflictual deben hacerse a esas cláusulas del acuerdo para llegar a la norma de conflicto idónea que permita determinar el Derecho aplicable al mismo. Estas cuestiones se estudiarán en posteriores trabajos, no siendo objeto del presente en el que nos encontramos.

\section{El concepto de acuerdo prematrimonial}

4. Los acuerdos prematrimoniales son pactos o contratos entre futuros cónyuges que suelen tener como finalidad la regulación de los efectos económicos o incluso personales de una posible ruptura matrimonial futura ${ }^{5}$. Su origen es anglosajón, aunque como se estudiará más adelante son regulados en algunos ordenamientos forales como el catalán y cada vez más aceptados por nuestros tribunales. Una de las

3 Vid. B. AÑoveros Terradas, "Los pactos prematrimoniales en previsión de ruptura en el Derecho Internacional privado", AEDIPr, t.X, 2010, pp. 462-469; A.L. Calvo Caravaca/J. Carrascosa GonzÁlez, "Efectos del matrimonio", Derecho Internacional Privado, decimoséptima ed., vol. II, pp. 259-261.

4 DOUE L 183/1, de 8 de julio de 2016.

5 Sobre el concepto de acuerdos prematrimoniales en la doctrina española, L. AguILAR RuIz, "Los pactos prematrimoniales. Vigencia y actualidad en el nuevo Derecho de familia", en Estudios Jurídicos en homenaje al Profesor José María Miquel, Aranzadi, 2014, pp. 107-108; I. ANTÓN JuÁREZ, "Acuerdos prematrimoniales: Ley aplicable y Derecho comparado", Cuadernos de Derecho Transnacional, Vol.7, núm. 1, marzo 2015, pp. 5 y ss.; F. J. Colao MARín, Los acuerdos prematrimoniales en el Derecho civil español, Dykinson, Madrid, 2018, pp. 25-29;M. ${ }^{\text {a }}$ P. GARCía RuBIO, "Los pactos prematrimoniales de renuncia a la pensión compensatoria en el Código civil", Anuario de Derecho civil, IV, 2003, p. 1655; J.P. GonzÁLEZ Del Pozo,"Acuerdos y contratos prematrimoniales (I)", Boletín de Derecho de familia, n. ${ }^{\circ}$ 81, julio 2008, p. 11; C. Martínez Escribano, Pactos prematrimoniales, Tecnos, Madrid, 2011, pp. 78 y ss.; M. Medina Alcoz,, "Pactos prematrimoniales, "pacta sunt servanda» y modificación sobrevenida de las circunstancias", en M. Pereña Vicente/ P. Delagado Martín (Dirs.) Nuevas Orientaciones del Derecho Civil en Europa, Thomson Reuters-Aranzadi, Cizur Menor (Navarra), 2015, pp. 773-774; A. J. Pérez Martín, Pactos prematrimoniales. Capitulaciones matrimoniales. Convenio regulador. Procedimiento consensual, Lex nova, Valladolid, 2009, p. 43; En la doctrina extranjera, C. BIEMMILLER, «The uncertain enforceability of prenuptial agreements: Why the «extreme» aproach in Pennsylvania is the right aproach for review», 6 Drexel Law. Review, 133, 2013-2014, pp. 137 y ss; B. Clark, «Prenuptial contracts in English Law: capricious outcomes or legislative clarification», Journal of Social Welfare \& Family Law, Vol. 32, n. ${ }^{\circ}$ 3, September 2010, p. 237; B. HaLE, «Equality and autonomy in family law», Journal of Social Welfare \& Family Law, Vol. 33, n. ${ }^{\circ}$ 1, March 2011, pp. 3-14; N. Lowe, «Prenuptial Agreements», Indret, 1, 2008; J.M SChERPE, «Los acuerdos matrimoniales en Inglaterra y Gales tras Radmacher v. Granatino», Indret, 2012, pp. 5 y ss; ID.,"Marital Agreements and Private Autonomy in Comparative Perspective", en J.M Scherpe, Marital Agreements and Private Autonomy in comparative perspective, Hart Publishing, Oregon, 2012, p. 487. 
razones de porque esto es así es debido a que en el ordenamiento español se admite legalmente desde hace mucho tiempo que los cónyuges pueden hacer pactos que regulan los efectos económicos de su matrimo$n^{6}{ }^{6}$. Uno de ellos es la posibilidad de que los cónyuges modifiquen el régimen económico matrimonial supletorio $^{7}$. No hay que olvidar que en el ordenamiento jurídico español existe un negocio jurídico concreto para canalizar los acuerdos entre cónyuges, las capitulaciones matrimoniales (arts. 1325-1335 CC) ${ }^{8}$.

5. Los capítulos matrimoniales se pueden celebrar antes o después del matrimonio (art. 1326 $\mathrm{CC}$ ), y mucho del contenido que se señala en capitulaciones matrimoniales puede coincidir con un acuerdo prematrimonial y convertirse, en realidad, en instrumentos homogéneos. Es así porque la mayoría de la doctrina civilista española ha aceptado un concepto amplio de capítulos matrimoniales 9 . De este modo, se acepta que en las capitulaciones matrimoniales se puedan hacer previsiones económicas que van más allá de lo relativo al régimen económico matrimonial, quedando incluidos aspectos que se refieran también a prever los efectos de una futura ruptura ${ }^{10}$.

6. Aun así, no hay que olvidar que las capitulaciones matrimoniales tienen una restricción en cuanto a la forma, ya que se exige legalmente la necesidad de que se formalicen en escritura pública (art. 1327 CC). Sin embargo, esa rigidez formal, como posteriormente estudiaremos, no se puede predicar a la luz del ordenamiento jurídico español que recaiga también sobre los acuerdos prematrimoniales que

6 La Ley 14/1975, de 2 de mayo, sobre reforma de determinados artículos del Código Civil y del Código de Comercio sobre la situación jurídica de la mujer casada y los derechos y deberes de los cónyuges ( BOE núm. 107, de 5 de mayo de 1975), es la que introdujo aspectos tan transcendentales como que la mujer tuviera capacidad jurídica y, por tanto, que pudiera actuar en el tráfico económico sin la representación de su marido o la legalidad de realizar capitulaciones matrimoniales una vez celebrado el matrimonio La posterior entrada en vigor de la Constitución española y de la Ley 30/1981, de 7 de julio, por la que se modifica la regulación del matrimonio en el Código Civil y se determina el procedimiento a seguir en las causas de nulidad, separación y divorcio (BOE núm. 172, de 20 de julio de 1981), determinó que partir de esta época es cuando se podría legalmente hablar de la posibilidad de realizar un acuerdo prematrimonial en el ordenamiento español.

Muy interesante la reflexión sobre que la novedad de los acuerdos prematrimoniales es más aparente que real que realiza la profa. Ma D. Cervilla Garzón en "Reflexiones en torno a los acuerdos prematrimoniales con previsiones de ruptura en nuestro derecho actual. A propósito de la Sentencia del TS de 24 de junio de 2015", C. Lasarte/Mà.D. Cervilla, Ordenación económica del matrimonio y de la crisis de pareja, Tirant lo Blanch, Valencia, 2018, pp. 229-230. La autora señala que en el ordenamiento jurídico español ha existido la tradición de que los futuros cónyuges puedan incluso antes de haber celebrado el matrimonio cambiar el régimen legal supletorio por otro que consideren más adecuado para ellos. Esta autonomía de la voluntad de los cónyuges en relación al régimen económico matrimonial no se prevé en otros ordenamientos extranjeros como el inglés o el estadounidense, ya que en ellos simplemente no existe (salvo en el Estado de California y Lousiana) la figura del régimen económico matrimonial. Así, por ese motivo, en los años 70 del pasado siglo en atención a los diferentes asuntos que llegaban a los tribunales se fue forjando un régimen jurídico sobre los acuerdos entre cónyuges. La realidad es que no le falta razón a la citada autora. En el ordenamiento inglés y también en el estadounidense estos acuerdos se consideraban contrarios al orden público por considerar que al hacer previsiones relativas antes del matrimonio respecto a un posible divorcio iba en contra del orden público por fomentar las rupturas. Hoy en día, esa visión está superada. Para un mayor detalle sobre cómo regulan estos ordenamientos los acuerdos prematrimoniales vid. ad ex. I. ANTÓN JUÁreZ, “Acuerdos prematrimoniales: Ley aplicable y Derecho comparado", Cuadernos de Derecho Transnacional, vol. 7, n 1, pp. 7-32. Vid. también. Mª.D. Cervilla Garzón, Los acuerdos prematrimoniales en previsión de ruptura, Tirant lo Blanch, Valencia, 2013, pp. 57-143.

8 Sobre las capitulaciones matrimoniales vid. sin carácter exhaustivo, V. Guilarte Gutiérrez/ C. Guilarte MartínCalero/C. Martínez Escribano/ N. Raga Sastre, "Las capitulaciones matrimoniales. Las donaciones por razón del matrimonio", en M. Yzquierdo Tolsada / M. Cuena Casas (Dirs.), Tratado de Derecho de Familia, vol. III, $2^{\text {a }}$ ed., Thomson Reuters Aranzadi, Navarra, 2017, pp.491- 665.

9 A. Cabanilas Sánchez, “Comentario al art. 1325 del Código Civil”, en A. Cañizares Laso/ P.De Pablo Contreras Crespo/ F.J. Orduña Moreno/Ma R, Valpuesta Moreno (Dirs.), Código Civil Comentado, $2^{\mathrm{a}}$ ed., Thomson Reuters Aranzadi, Cizur Menor (Navarra), 2016, pp. 837-838; L. CABEZUElo ArenAS, “¿Es válida la renuncia a una eventual pensión compensatoria formulada años antes de la separación en capitulaciones matrimoniales?, págs. 2376 y 2377;Maa.D. CERVILla GaRzóN, Los acuerdos prematrimoniales en previsión de ruptura, Tirant lo Blanch, Valencia, 2013, p. 33; J. P. GonzÁlez del Pozo, “Acuerdos y contratos prematrimoniales (I)", Boletín de Derecho de familia, no 81, julio 2008, p. 11; V. Guilarte Gutiérrez/ C. Guilarte Martín-Calero/C. Martínez Escribano/ N. Raga Sastre, "Las capitulaciones matrimoniales. Las donaciones por razón del matrimonio", en M. Yzquierdo Tolsada / M. Cuena Casas (Dirs.), Tratado de Derecho de Familia, vol. III, $2^{\text {a }}$ ed., Thomson Reuters Aranzadi, Navarra, 2017, pp. 493-495;A. L ReBolLEDo VARELA, "pactos en previsión de la ruptura matrimonial", Libro Homenaje al Profesor Cuadrado Iglesias, Vol. I, Aranzadi, 2008, p. 741; L. Zarraluqui Sánchez- Eznarriaga, Derecho de familia y de la persona, Tomo 4, Bosh, Barcelona, 2007. p. 31.

10 Vid. sobre este particular, E.Rodriguez GuITIÁN, Los pactos de pre-Ruptura ..., p. 140. 
solo tienen como objetivo hacer previsiones sobre una posible ruptura. Dicho pacto se podría contener en un acuerdo privado y podría ser formalmente válido.

7. Por esa libertad de forma y también de fondo que vamos a ir apreciando a lo largo del trabajo que reina en el Derecho civil español, los acuerdos prematrimoniales son cada vez negocios jurídicos más presentes en nuestros días. Los acuerdos que prevén los efectos de una futura crisis matrimonial no sólo pueden realizarse antes de que el matrimonio se celebre. También es posible que los pactos en previsión de ruptura se celebren durante el matrimonio incluso una vez que la crisis ha tenido lugar ${ }^{11}$. De este modo, sería posible diferenciar en atención al criterio temporal entre los acuerdos prematrimoniales, los acuerdos matrimoniales y los acuerdos celebrados una vez existe la crisis matrimonial. En particular, el objeto del presente estudio se centra en el análisis de los pactos que se formalizan entre los cónyuges antes de la celebración del matrimonio y con el objetivo de prever una futura crisis matrimonial. Como ya ha señalado la doctrina, los pactos prematrimoniales son prospectivos y previsores ${ }^{12}$. Se celebran antes de contraer matrimonio. Su objetivo es prever problemas que pueden surgir con una ruptura matrimonial e intentar dar soluciones de forma anticipada sin necesidad de que sea un tercero (un juez) el que deba decidir por los cónyuges ${ }^{13}$.

\section{La revisión de los acuerdos prematrimoniales ante jueces españoles: ¿Cómo elaborar un acuerdo prematrimonial eficaz a prueba de revisiones judiciales posteriores tanto desde una pers- pectiva conflictual como material?}

\section{Aproximación inicial}

8. Los acuerdos prematrimoniales debido a la materia sobre la que versan y por quiénes se realizan hace necesario que se tenga presente en el momento de su celebración disposiciones que van más allá de lo aplicable de forma general a los contratos (art. $1255 \mathrm{CC}^{14}$ o del art. $1328 \mathrm{CC}^{15}$ ). Sin embargo, esa necesidad de unos requisitos "extras" o adicionales para que puedan desplegar eficacia los acuerdos prematrimoniales, no se recoge en la legislación civil común. Esto es así debido a que en la misma no hay una regulación expresa sobre los acuerdos prematrimoniales en previsión de ruptura ${ }^{16}$. No sucede lo mismo en determinadas legislaciones forales, como la catalana, donde en el art. 231.20 de la Ley 25/2010, de 29 de julio, del libro segundo del Código Civil de Cataluña, relativo a la persona y la familia recoge expresamente los requisitos que debe tener un acuerdo en previsión de ruptura, por ende, un acuerdo prematrimonial para ser considerado válido ${ }^{17}$.

11 SAP Girona (sección $1^{\text {a }}$ ) núm. 369/2013 de 1 de octubre de 2013, ECLI:ES:APGI:2013:858, FJ $3^{\circ}$.

12 M. Medina Alcoz/Ma . M. Heras Hernández/ M. Iglesias Caridad, "Capitulaciones Matrimoniales, Pactos prenupciales y pactos de organización de las parejas estables no casadas”, en M. YzquIERdo Tolsada (Dir.), Contratos mercantiles, públicos, laborales e internacionales con sus implicaciones tributarias, Vol. IV, Thomson Reuters Aranzadi, Navarra, 2014, p. 480. Anteriormente ya había señalado estas características, M.P. GARCíA RUBIO, "Los pactos prematrimoniales de renuncia a la pensión compensatoria en el Código Civil”, Anuario de Derecho civil, IV, 2003, p. 1655.

13 Resulta curiosa una tendencia actual, al menos presente en EE.UU., que consiste en la realización de acuerdos prematrimoniales que tienen como objetivo paliar los efectos de un posible divorcio pero los futuros contrayentes exigen a sus abogados que no incluyan la palabra divorcio en el texto del acuerdo, Vid sobre este particular, M. CUSHING DoHERTY, $<<$ Romantic Premarital Agreements: Solving the Planning Issues Without "The D Word">>, American Academy of Matrimonial Lawyers, vol. 29, $\mathrm{n}^{\mathrm{o}} 1,2016$, donde la autora señala que pueden existir diferentes motivos por los que los futuros contrayentes no quieren incluir la palabra divorcio en su acuerdo prematrimonial, entre los mismos ad ex., profesar una determinada religión.

14 "Los contratos pueden establecer los pactos, cláusulas y condiciones que tengan por conveniente, siempre que no sean contrarios a las leyes, a la moral y al orden público".

15 "Será nula cualquier estipulación contraria a las Leyes o a las buenas costumbres o limitativa de la igualdad de derechos que corresponda a cada cónyuge".

16 Esta cuestión ya lo abordamos previamente en I. ANTÓN JUÁREZ, “Acuerdos prematrimoniales: Ley...”, p. 33; También lo ha señalado más doctrina vid ad ex. F. LACABA SÁnchez, "Pactos prematrimoniales (en previsión de ruptura)", Revista de Derecho vlex, $\mathrm{n}^{\circ}$ 148, septiembre 2016, p. 2; A. Rodriguez GuItí́n, Los pactos de pre-Ruptura conyugal, Aranzadi, Cizur Menor(Navarra), 2018, p. 127.

17 BOE núm. 203, de 21 de agosto de 2010. 
9. A pesar de carecer de regulación expresa en el Derecho civil común, los acuerdos celebrados antes del matrimonio en previsión de un posible divorcio o separación son acuerdos ampliamente admitidos por la doctrina y la jurisprudencia debido a que es un reflejo del libre ejercicio de la autonomía de la voluntad por los cónyuges. No obstante, y como señalábamos, aunque la admisión de estos acuerdos no se discute en la actualidad. Sí que es cierto que, en ocasiones, no se tiene claro, especialmente por parte de los asesores que tienen que redactar este tipo de pactos sobre la eficacia de los mismos cuando ha transcurrido un tiempo considerable desde que se celebraron.

El motivo de esa incertidumbre suele ser porque el acuerdo debe enfrentarse a una revisión judicial debido a que en el momento de su ejecución una de las partes no quiere que lo ahí dispuesto despliegue efectos. Este desacuerdo hace que la intervención de los tribunales esté asegurada. Así, con el fin de brindar seguridad jurídica a las partes que pudieran estar interesadas en este tipo de pactos, y con el fin de ofrecer un asesoramiento preciso, se ha podido llegar (tras el estudio de la doctrina y de la jurisprudencia sobre la materia) a un posible test que permitiría analizar ex post si un acuerdo prematrimonial puede desplegar efectos en el ordenamiento jurídico español en atención a las normas de Derecho internacional privado españolas y Derecho civil común español. Como ya advertíamos al inicio, hacemos referencia a las normas de Derecho internacional privado porque muchos de los acuerdos que llegan a los tribunales son celebrados en el seno de matrimonios mixtos matrimonios deslocalizados.

Desde nuestro punto de vista, cuando se realiza un acuerdo prematrimonial con elemento extranjero, la cuestión se complica. Esto es así porque ya no sólo se debe tener en cuenta el ordenamiento por el que se rige el pacto sino también los posibles tribunales que podrían acabar revisando el acuerdo. Y éstos no tendrían por qué ser los del ordenamiento que rige el pacto. De este modo, las consideraciones de Derecho internacional privado, de Derecho material comparado y las del propio ordenamiento pueden llegar a ser igual de importantes a tener en cuenta a la hora de prestar asesoramiento sobre un pacto prematrimonial internacional.

10. A nuestro entender, este test que vamos a exponer no es en todos sus aspectos es imperativo. El no cumplimiento de algunos de los criterios que vamos a analizar no implica que el acuerdo no pueda ser considerado válido y eficaz por un juez en atención al Derecho español y las circunstancias del caso concreto. No obstante, la realidad es que si un acuerdo prematrimonial cumple con los aspectos que vamos a señalar las probabilidades de superar una posterior revisión judicial ante jueces españoles son muy altas.

11. Este test básicamente consistiría en analizar determinados criterios en dos momentos diferentes: al momento de la celebración del acuerdo y al momento de la ejecución.

En el momento de la celebración, como ya ha señalado la doctrina civilista española, sería necesario precisar cómo se forjó ese consentimiento, cual fue la forma de celebración del acuerdo y si las partes contaron con capacidad suficiente para celebrarlo ${ }^{18}$.

En cuanto al momento de la ejecución del acuerdo, es necesario verificar en atención al contenido del acuerdo qué circunstancias tienen los cónyuges en ese momento y si difieren o no de las que existían al momento de celebrar el acuerdo. Así, en esta fase será importante tener dos reglas presentes: pact sunt servanda y rebus sic stantibus.

\section{Requisito 1: la capacidad de las partes}

\section{A) La determinación de la Ley aplicable a la capacidad de las personas físicas}

12. En cuanto a la capacidad, señalar que desde un punto de vista internacional privatista, es necesario tener en cuenta las normas españolas de Derecho internacional privado en cuanto a la capacidad de las personas físicas. De forma breve, simplemente señalar que, en relación a todos los

18 Per alia, vid. A .Rodriguez Guitián, Los pactos de pre-Ruptura..., pp. 133 y ss. 
aspectos relativos al régimen económico matrimonial va a ver a partir del 29 de enero de 2019 un sistema doble sobre la materia. Así, para los matrimonios celebrados con anterioridad a esa fecha se van a aplicar las normas de Derecho internacional privado españolas creadas por el legislador español, estas serían los arts. 9.2 y $9.3 \mathrm{CC}$. Sin embargo, para los matrimonios posteriores a esa fecha se van aplicar las normas de Derecho internacional privado europeas contenidas en el RREM. De hecho, pueden existir un tercer grupo de matrimonios donde sus efectos queden regidos por los dos sistemas. Esto sucede cuando el matrimonio se ha celebrado con anterioridad al 29 de enero de 2019 pero han elegido posteriormente y a través de capitulaciones matrimoniales la ley aplicable a su régimen económico. En este último caso, las normas de Derecho internacional privado nacionales determinarán el régimen económico matrimonial desde la celebración del enlace hasta la aplicación del RREM (29 enero 2019) y las normas de derecho internacional privado europeas (RREM) desde la fecha de su aplicación hasta la disolución del régimen ${ }^{19}$.

13. Volviendo a la ley aplicable a la capacidad, debido a que este aspecto está excluido del ámbito de aplicación material del RREM (art. 1.2.a.) la norma de conflicto para determinar el Derecho aplicable con el fin de determinar si una persona física ostenta capacidad para celebrar un acuerdo prematrimonial sería el art. 9.1 CC ${ }^{20}$. Esta norma señala que la capacidad se rige por la Ley nacional de las personas físicas ${ }^{21}$.

No obstante, no toda la doctrina, ha apoyado que sea la Ley personal la ley que rija la capacidad de los contrayentes para celebrar acuerdos matrimoniales ${ }^{22}$. Desde hace tiempo se ha propuesto que sea la Ley aplicable a la validez del acuerdo celebrado entre los cónyuges. Esta opción resulta positiva cuando la ley aplicable a la capacidad y la ley aplicable a la validez del negocio jurídico no coinciden y además presentan exigencias diferentes ${ }^{23}$. También esta visión es interesante para reforzar la tesis de que sea una única ley la aplicable al acuerdo prematrimonial para determinar su validez. En definitiva, sea la ley personal de los futuros cónyuges o la ley aplicable a la validez del negocio jurídico lo importante es que la autoridad competente pueda comprobar que las partes disponían de capacidad jurídica para celebrar el acuerdo prematrimonial y evitar situaciones jurídicas claudicantes.

14. Así, por tanto, utilizando el punto de conexión de la ley nacional se podría plantear en el siguiente ejemplo: la Sra. Lorena Díaz de nacionalidad español y el Sr. John Smith de nacionalidad filipina firman un acuerdo prematrimonial en el Estado de California en noviembre de 2017. Ambos acuerdan que sea el Derecho de ese State el que rija el acuerdo, ya que esa la residencia habitual de ambos al momento de la firma del pacto. Tras escasamente un año de matrimonio, la esposa solicita el divorcio ante tribunales españoles y solicita que se cumpla una de las disposiciones del acuerdo donde se señala que ella tras un divorcio sería titular en un $15 \%$ de un fondo de inversión ubicado en Las Bahamas. El juez español para determinar cualquier cuestión relativa al pacto prematrimonial debe determinar si éste es válido. El primer requisito a comprobar es si los cónyuges disponían de capacidad. El juez español debe aplicar sus normas de Derecho internacional privado para determinar la Ley aplicable al acuerdo. El art. 9.1 CC llevará al juez español a aplicar el Derecho español para la esposa y el Derecho filipino para el esposo. Estas leyes aplicables a la capacidad, sin embargo, no van a coincidir con la Ley aplicable al acuerdo, que en principio va a ser el Derecho del State de California.

19 Ya advierte sobre ello B. AÑoveros TerRadAs, "El régimen conflictual de las capitulaciones en los nuevos reglamentos de la Unión Europea en materia de regímenes económicos matrimoniales y efectos patrimoniales de las uniones registradas", AEDIPr., t. XVII, 2017, pp. 832-833

20 Vid. I. Antón JuÁrez, "Los acuerdos prematrimoniales en Derecho Internacional privado español”, Revista de estudios socio jurídicos, Bogotá (Colombia), enero 2019, pp. 74-75.

${ }_{21}$ Para un mayor detalle sobre la ley que debe regir la capacidad de las contrayentes para celebrar acuerdos matrimoniales vid. P. Diago Diago, Pactos o capitulaciones matrimoniales en Derecho Internacional privado, El Justicia de Aragón, Zaragoza, 1999, pp. 77-90.

22 M. A. Amores Conradí, "La nueva ordenación de la ley aplicable a los efectos del matrimonio", Revista Jurídica de Castilla-La Mancha, (11-12), 1991, pp. 79-84.

23 Cuando se da esta situación la doctrina internacional privatista ya ha previsto soluciones, vid. E. RodríGuez PINEAU, Régimen económico matrimonial, Comares, Granada, 2002, p. 74. 
15. En contraposición, teniendo en cuenta como punto de conexión la Ley aplicable a la validez del contrato, podríamos plantear este otro ejemplo: el Sr. Gonzalo Ramírez, nacional español y la Sra. Mayer de nacionalidad inglesa, acuerdan un pacto prematrimonial pocos días antes de su enlace, febrero de 2019. El citado acuerdo señala que la Ley aplicable al mismo es el Derecho inglés. Este acuerdo tiene un fin concreto y es proteger el patrimonio privativo de la futura esposa. Ella, hija de un rico empresario inglés del mundo audiovisual, no quiere que en caso de divorcio pueda verse expuesta a algún tipo de reclamación por parte de su futuro esposo que haga que su patrimonio pueda disminuir. Tras el enlace, la pareja fija su residencia habitual en España. En el caso hipotético de una posible ruptura tras varios años de matrimonio y que no haya acuerdo en la ejecución de ese pacto prematrimonial, será un juez el que deba decidir sobre la validez del mismo. Como ya se ha sostenido, el primer requisito para determinar la validez, es precisar si las partes tenían capacidad para celebrar el acuerdo. Si seguimos la tesis de que debe ser la Ley que rige la validez del acuerdo la que determine si las partes tenían capacidad para la realización de ese negocio jurídico será necesario acudir al Derecho inglés. En el caso de que esa elección de ley sea válida, va a tener una función doble. El Derecho inglés va a servir para determinar la capacidad de las partes pero también la validez material del acuerdo.

\section{B) EI Derecho español como derecho material aplicable a la capacidad}

16. En particular, en el caso del Derecho español, para determinar si una persona es capaz para celebrar un acuerdo prematrimonial ésta debe ser mayor de edad y disponer de plena capacidad de obrar. No obstante, también hay que señalar los arts. 1329 y 1330 CC. Estos preceptos permiten que el menor no emancipado que con arreglo a la Ley pueda casarse pueda también otorgar capitulaciones matrimoniales, pero necesitará la autorización de sus padres o tutor, salvo que el pacto vaya dirigido simplemente a modificar el régimen económico matrimonial. En el caso del incapacitado judicialmente, sólo podrá otorgar capitulaciones con la asistencia de sus padres, tutor o curador. Hay doctrina que precisa que lo señalado en cuanto a la capacidad debería aplicarse sólo en el caso de pactos que regulan aspectos económicos ${ }^{24}$. Así, en el caso de que el acuerdo recogiera aspectos personales debería el acuerdo ser celebrado en todo caso por personas mayores de edad y con plena capacidad de obrar debido a la transcendencia que pueden presentar para los futuros contrayentes tales disposiciones personales ${ }^{25}$.

\section{Requisito 2: forma del acuerdo}

\section{A) Cuestiones de Derecho Internacional privado}

17. Desde un punto de vista internacional privatista, para saber cuál es la Ley aplicable a la forma de un acuerdo prematrimonial internacional es necesario tener presente el momento temporal en el que se celebró el acuerdo. Si éste se celebró con anterioridad del 29 de enero de 2019 será de aplicación el art. $11 \mathrm{CC}^{26}$. Sin embargo, si el acuerdo se celebró con posterioridad a dicha fecha será de aplicación el art. 25 RREM. Aunque en este Reglamento europeo no se señala de forma expresa a los acuerdos prematrimoniales en previsión de ruptura, ya que en su texto de la versión española recoge el término "capitulaciones matrimoniales". Consideramos que los acuerdos prematrimoniales hasta que se pronuncia el TJUE al respecto y lo haga en sentido contrario, entendemos que podrían tener cabida dentro de ese término de acuerdos entre cónyuges que maneja el RREM en lo relativo a las previsiones relativas al régimen económico matrimonial.

18. Así, por lo tanto, en el citado art. 25 RREM el legislador europeo recoge una serie de requisitos mínimos que los acuerdos entre cónyuges deberían seguir cuando es de aplicación el citado Reglamento europeo. Estos requisitos formales, que serán exigibles a partir del 29 de enero de 2019, a los acuerdos prematrimoniales internacionales que se celebren en España o en algunos de los otros

24 C. Martínez Escribano, Pactos prematrimoniales, Tecnos, Madrid, 2011, p. 212.

25 Ibidem, p. 212.

26 Para un mayor detalle sobre este precepto vid. I. ANTÓN JuÁREZ, "Los acuerdos prematrimoniales..., p. 76. 
quince Estados partes de la cooperación reforzada, son los siguientes: 1) el acuerdo debe constar por escrito; 2) debe recoger la fecha de su celebración; 3) el acuerdo debe ser firmado por ambos cónyuges. Además, el mismo art. 25 recoge que el acuerdo debe ser válido formalmente en atención a la Ley del Estado miembro de la residencia habitual común o de cualquiera de los cónyuges en el momento de la celebración del acuerdo y que si la Ley que rige el régimen económico matrimonial impone requisitos formales adicionales dichos requisitos son de aplicación ${ }^{27}$.

\section{B) Cuestiones materiales}

19. En atención al derecho material español, lo que se verifica es si el acuerdo se ha celebrado ante notario, y por tanto, se ha elevado a escritura pública o es un acuerdo privado entre los cónyuges. Como ya ha señalado, la mayoría de la doctrina civilista española está de acuerdo en que existe la libertad de forma en la realización de los acuerdos prematrimoniales ${ }^{28}$. Éstos podrían ser perfectamente válidos si se redactan por escrito en documento privado sin necesidad de acudir al notario.

20. Desde nuestro punto de vista, es recomendable acudir al notario para celebrar un acuerdo prematrimonial en previsión de ruptura. Esta recomendación descansa especialmente en la labor de asesoría que puede ejercer el notario ${ }^{29}$. Éste les puede advertir de aspectos que pueden ser controvertidos y que pueden plantear problemas de validez en un futuro. Además, es una vía idónea para poder probar el acuerdo y para poder inscribirlo posteriormente en algún registro público como en el Registro de la Propiedad ${ }^{30}$. El hecho de acudir al notario a celebrar el acuerdo implica unas garantías de validez para el tribunal de las que el pacto privado carece ${ }^{31}$. Se podría decir que la forma pública del acuerdo tiene un impacto directo en percepción del juzgador sobre el acuerdo. El juez al celebrarse el acuerdo ante notario tiene una mayor garantía de que los futuros cónyuges ostentaban capacidad para realizar el acuerdo y estaban prestando el consentimiento sobre un negocio que les había explicado previamente.

\section{Requisito 3: el consentimiento}

\section{A) Aspectos relativos a la Ley aplicable}

21. En relación a la determinación de la Ley aplicable al consentimiento dicha Ley debería ser la misma que se aplica para determinar la validez material del acuerdo (art. 24 RREM). Posteriormente nos

27 Para un estudio más detallado sobre el RREM, vid sin carácter exhaustivo en la doctrina internacional privatista española P. QuinzÁ Redondo, Régimen económico matrimonial: aspectos sustantivos y conflictuales, Tirant lo Blanch, Valencia, 2016; A. Rodríguez Benot, "Los Reglamentos de la UE en materia de sucesión por causa de muerte y de régimen económico matrimonial: justificación y caracteres comunes", en E.M. Vázquez Gómez, M.D. Adam Muñoz y N. Cornago Prieto (coords.), El arreglo pacifico de controversias internacionales, Valencia, Tirant lo Blanch, 2013, pp. 583-591.J. Rodríguez Rodrigo, "Régimen económico matrimonial de las parejas registradas", en A.L.CAlvo CARAVACa/J. Carrascosa GonzÁlez, Derecho internacional privado, vol II, decimoctava edición, Comares, Granada, pp. 161-226. En la extranjera, vid. ad ex., K. BoELE-WoELKI, "Property relations of international couples in Europe: the interaction between unifying and harmonizing instruments", en Grenzen Überwinden, Prinzipen bewahren: Fretshrift fÜr Bernd Hoffmann, 2011, pp. 63-72;I. VIarengo, "The EU Proposal on matrimonial property regimes, some general remarks" Yearbook of Private International Law, vol. 13, 2011, pp. $199-215$.

28 Per alia vid C. Martínez Escribano, Pactos prematrimoniales..., pp. 208-209.

29 A .Rodríguez Guitián, Los pactos de pre-Ruptura ..., p. 141; Vid. también, A. Serrano de Nicolás, "Los pactos en previsión de una ruptura matrimonial en el Código Civil de Cataluña", en R. BArrada Orellana/M. Garrido Melero/S. NASARRE Aznar, El nuevo derecho de la persona y de la familia: libro segundo del Código Civil de Cataluña, Barcelona, Bosh, 2011, p. 359 .

${ }_{30} \mathrm{M}^{\mathrm{a}}$. P. GARCía RuBIO, $<<$ Los pactos prematrimoniales de renuncia a la pensión compensatoria en el Código Civil $>>$, Anuario de Derecho civil, IV, 2003, p. 1660.

31 Que la forma en la que se adopta el pacto prematrimonial es relevante y que presenta garantías ha sido señalado por la doctrina desde hace tiempo vid ad ex. S. GASPAR LERA, "Acuerdos prematrimoniales sobre relaciones personales entre cónyuges y su ruptura: límites a la autonomía de la voluntad", $A D C$, tomo LXIV, 2011, fasc. III, p. 1072; C. PinTo Andrade, "La genérica validez de los pactos en previsión de ruptura matrimonial", Revista de Derecho de familia, no 49, 2010, p. 71; E. Roca Trías, "Autonomía, crisis matrimonial y contratos con ocasión de crisis", en J. M. Abril CAmpoy/ M.E. Amat Llari (Coords.), Homenaje al Profesor Lluis Puig i Ferrol, Tirant lo Blanch, Valencia, pp. 2116-2117. 
detendremos en ella cuando se analice el contenido del pacto prematrimonial. Esta es la línea que siguen otros Reglamentos europeos como el Reglamento (CE) $N^{o}$ 593/2008 del Parlamento y del Consejo de 17 de junio de 2008 sobre la ley aplicable a las obligaciones contractuales (en adelante, Roma I) que considera que para saber si las partes han prestado su consentimiento a un contrato es necesario aplicar la ley que rige la validez del contrato ${ }^{32}$.

22. Para los acuerdos que se celebraron con anterioridad a la fecha de aplicación del Reglamento europeo también consideramos que se debería aplicar la Ley aplicable a la validez del acuerdo, ya que es una ley que facilita la labor del juez ${ }^{33}$. No obstante, señalar que hay doctrina que ha considerado que la Ley aplicable para determinar el consentimiento debería ser la Ley nacional, de la misma manera que sucedería con la capacidad ${ }^{34}$.

\section{B) Aspectos materiales sobre el consentimiento}

23. Si el Derecho aplicable al consentimiento resultara el Derecho material español, se puede señalar que como consecuencia de esa naturaleza "especial" de los acuerdos prematrimoniales, se puede decir que si se cumplen determinados aspectos se podría presumir que los futuros cónyuges han prestado un consentimiento informado. Estos aspectos serían básicamente dos ${ }^{35}$ : 1) Asesoramiento legal independiente; 2) Conocimiento de la situación financiera entre los cónyuges.

Estos criterios no sólo los ha tenido presentes la doctrina, también así se han recogido por el legislador catalán (art. 231-20 Código Civil de Cataluña) evidentemente influenciado por el Derecho de algunos States de Estados Unidos. Otro criterio o indicio para probar que el consentimiento se forjó libremente y sin vicios es que haya transcurrido un tiempo (días, semanas o incluso meses), entre la celebración del acuerdo prematrimonial y la celebración del enlace. Ese tiempo permitiría presumir que el pacto no se celebró apresuradamente y en un estado emocional que permitía conocer a los futuros cónyuges el documento que firmaban. A nuestro juicio, siguiendo a la jurisprudencia ${ }^{36}$ y también a la doctrina ${ }^{37}$ entendemos que es un criterio orientador para el Derecho español ${ }^{38}$. El transcurso de un tiempo entre la celebración del acuerdo y el enlace es recomendable pero en ningún caso un aspecto que pudiera hacer nulo el acuerdo.

24. En cuanto al asesoramiento legal independiente, decir que este es especialmente necesario cuando uno o ambos cónyuges no tienen conocimientos jurídicos. En nuestra opinión, el asesoramiento legal resultaría muy aconsejable, en prácticamente todos los casos. Esto lo consideramos así porque aunque se tengan conocimientos jurídicos, se trata de un negocio jurídico muy concreto que puede presentar unas implicaciones económicas e incluso personales que no se esperan si no se conoce bien la figura. $\mathrm{Ni}$ que decir tiene que este asesoramiento se hace imprescindible cuando el otro cónyuge no conoce del

32 DOUE L 177/6, de 4 de julio de 2008.

33 Para un mayor detalle sobre este particular, vid. I. ANTÓN JUÁREZ, “Los acuerdos prematrimoniales en...”, pp. 75-76. Vid. también, J. Rodríguez Rodrigo, “Capítulo 29. Régimen económico matrimonial. Aspectos internacionales”, en M. YzQuierdo Tolsada y M. Cuena Casas (Dirs.), Tratado de derecho de familia, volumen 4, pp. 489-620. Thomson Reuters Aranzadi, Navarra, p. 601.

34 Vid. J. Carrascosa GonzÁlez, Matrimonio y elección de ley. Estudio de Derecho internacional privado, Comares, Granada, 2001, pp. 170-171

35 Vid. C. Martínez Escribano, Pactos prematrimoniales..., pp. 199-208. Más reciente, en el mismo sentido, A. RodríGUEz Guitín, Los pactos de pre-Ruptura..., pp. 143-161.

36 Sentencia de la Audiencia Provincial de Girona de 1 de marzo de 2004(JUR 2004/118887), donde se admite la renuncia a una pensión compensatoria realizada en escritura pública diez días antes de la celebración del enlace; Sentencia de la Audiencia Provincial de Barcelona de 23 de marzo de 2010(JUR 2010, 175675), en la que el tribunal acepta el otorgamiento de capitulaciones tres días antes al del enlace.

37 C. Martínez Escribano, Pactos prematrimoniales..., p. 202; E . Rodriguez Guitián, Los pactos de pre-Ruptura ..., p. 163.

38 No así puede entenderse para el Derecho civil catalán en el que se recoge de forma expresa en el art. 231.20 de la Ley 25/2010, de 29 de julio, del libro segundo del Código Civil de Cataluña “(...)En el supuesto de que sean antenupciales, solo son válidos si se otorgan antes de los treinta dias anteriores a la fecha de celebración del matrimonio(...)”. 
todo bien el idioma en el que se está redactando el acuerdo ${ }^{39}$. De hecho, cuando esta situación puede darse, a nuestro juicio lo más conveniente es celebrar un "acuerdo espejo". Es decir, que se redacte un acuerdo prematrimonial en castellano y otro en el idioma del otro cónyuge. Así, nunca se va a poder alegar que no se entendían las disposiciones del acuerdo. Esta práctica está extendida en el Derecho estadounidense cuando se está ante prenups con elemento extranjero. Esta traducción implica un mayor coste económico para los futuros cónyuges, pero verdaderamente si puede evitar un litigio posterior, se podría apreciar realmente como una inversión.

En atención al Derecho español, este asesoramiento sobre el acuerdo prematrimonial que los cónyuges pretenden celebrar puede realizarlo el notario ${ }^{40}$. Esta labor se encontraría dentro de sus funciones (art. 147 del Reglamento Notarial ${ }^{41}$ ). Este asesoramiento podría desarrollarse con independencia de que el acuerdo en previsión de crisis matrimonial se contenga en el instrumento típico de las capitulaciones matrimoniales o como acuerdo prematrimonial propiamente dicho ${ }^{42}$.En ambos casos el pacto entre los cónyuges se elevará a escritura pública y disfrutará de las mismas garantías jurídicas debido a que su celebración tiene lugar ante fedatario público.

A nuestro juicio, además del notario, el cual va a realizar una función neutral, sin velar en principio por los intereses de ninguna de las partes, sería importante también contar con el asesoramiento de un abogado experto en la materia ${ }^{43}$. De hecho, es lo que normalmente sucede en la práctica, ya que suele ser el abogado de uno de los contrayentes el que redacta el acuerdo. Esto sucede generalmente cuando el patrimonio privativo a proteger es abultado y con el acuerdo prematrimonial se persigue protegerlo ${ }^{44}$.

En particular, sobre el asesoramiento legal se podrían abordar en concreto tres interrogantes: 1) ¿la inexistencia de asesoramiento hace inválido el acuerdo prematrimonial en atención al Derecho español?; 2) ¿Debe prestarse el asesoramiento y dejar unos días de reflexión o puede celebrarse en el mismo momento del asesoramiento?; 3 ) ¿El mismo experto puede asesorar a ambos cónyuges o debe ser verdaderamente un asesoramiento independiente?

Respecto a las cuestiones que nos planteamos se podría decir que en términos generales, analizadas en su conjunto, el Derecho español es flexible al respecto. Esto implica que el hecho de que no exista un asesoramiento verdaderamente individual, que implique a dos abogados asesorando de forma separada a cada cónyuge el acuerdo vaya a ser nulo. Sin embargo, a nuestro juicio, es necesario que tener presente lo siguiente:

1) Si no existe asesoramiento legal, el acuerdo puede ser válido perfectamente en atención al Derecho civil común español ${ }^{45}$ y también al Derecho civil catalán ${ }^{46}$. Es un requisito deseable, muy aconsejable, que facilita la prueba de que el consentimiento es informado, pero a nuestro juicio, no es imprescindible para la validez del acuerdo. Si no ha existido asesoramiento legal a ninguno de los cónyuges por separado, ni si quiera a uno de ellos o incluso a ninguno (en la práctica este escenario es difícil que tenga lugar, salvo que se alguno de los futuros cónyuges sea jurista), el pacto puede ser válido si se prueba que el consentimiento ha sido informado, libre y sin vicios. De hecho, esta es la línea que se sigue en ordenamientos como el inglés tras la famosa sentencia Radmacher vs. Granatino ${ }^{47}$ y el estadounidense en

39 En esta sentencia de AP de Madrid de 27 de noviembre de 2011(JUR 2003/92806), de igual manera a como sucede en la STS de 30 de marzo de 2018 ( $n^{\circ}$ 1925/2018, ECLI:ES:TS:2018:1925) que comentaremos posteriormente, la mujer renuncia a la pensión compensatoria en unas capitulaciones matrimoniales y alega no entender bien el idioma en el que se redactan.

40 C. Martínez Escribano, Pactos prematrimoniales..., p. 203.

${ }_{41}$ Decreto 2 junio 1944, por el que se aprueba con carácter definitivo el Reglamento de la organización y régimen del Notariado (BOE núm. 189, de 7 de julio 1944).

42 A. Rodríguez GuItí́n, Los pactos de pre-Ruptura ..., p. 145.

43 Sobre este particular, vid. E . Rodriguez GuItIÁn, Los pactos de pre-Ruptura ..., pp. 151-154.

44 J.M. Sherpe, "Marital Agreements and Private Autonomy in Comparative Perspective", en J.M.SherPe (ed.), Marital Agreements and Private Autonomy, Hart Publishing, Oxforf-Portland, 2011, p. 493.

45 A. Rodríguez Guití́n, Los pactos de pre-Ruptura ..., p. 148.

46 L. Allueva Aznar, Prestación compensatoria y ..., p. 243

47 Radmacher v. Granatino [2010] UKSC 42, apartado 69, donde señala que aunque el asesoramiento legal es aconsejable no se le puede restar peso a un acuerdo prematrimonial porque no haya existido asesoramiento. El Tribunal Supremo inglés considera que lo relevante es que quede claro que las partes han tomado su decisión de celebrar el acuerdo conociendo todas 
la section 9 de los Uniform Premarital and Marital Agreements Act (en adelante, UPMAA) del año $2012^{48}$.

2) En la línea del razonamiento anterior, podemos decir que lo aconsejable es dejar un margen de tiempo, el que las partes consideren, entre que se recibe información sobre el acuerdo y se firma el mismo. Este lapso temporal permite que se pueda prestar un consentimiento reflexionado ${ }^{49}$. No obstante, si no se hace, se debe probar en caso de que se pueda poner en duda la validez del consentimiento los motivos por los que se firmó en el mismo momento en el que se recibe asesoramiento.

25. En cuanto a la información financiera, éste es otro de los criterios que permiten demostrar que el consentimiento de los cónyuges es informado. En la misma línea que cuando estudiamos el asesoramiento legal independiente, que los cónyuges se hayan informado sobre sus patrimonios al momento de la celebración del acuerdo es un indicio muy positivo de que se sabía lo que se estaba firmando. Esta información puede tener relevancia cuando en el acuerdo prematrimonial se renuncian a derechos o hay un gran desequilibrio patrimonial entre los cónyuges. Por lo tanto, en atención al Derecho civil español es posible sostener que la falta de información financiera o financial disclosure no hace inválido el acuerdo ${ }^{50}$. Sin embargo, es cierto que la falta de información financiera junto con la falta de otras "precauciones" al momento de celebrar el acuerdo pueden hacer que en caso de una revisión judicial posterior el juez considere que el consentimiento se formó sin tener un panorama general y global de la situación económica del otro. Esto le podría llevar a concluir que el acuerdo se firmó sin un consentimiento realmente informado, considerando que pudo haber un abuso de una parte frente a la otra. El resultado de esta consideración es que el acuerdo no pueda desplegar efectos.

A nuestro juicio, para evitar este resultado, siguiendo lo que se ha venido desarrollando en el Derecho de estadounidense ${ }^{51}$ en las últimas décadas se podrían destacar cuatro aspectos para que se pueda asesorar de forma correcta y precisa sobre el deber de prestar información financiera:

sus implicaciones. Entre los diferentes estudios doctrinales que analizan esta sentencia vid. I. ANTÓN JUÁREZ, "Acuerdos prematrimoniales: Ley aplicable y Derecho comparado", Cuadernos de Derecho Transnacional, vol. 7, no 1, pp 19-32.; B.CLARK, "Prenuptial contracts in English Law: capricious outcomes or legislative clarification", Journal of Social Welfare \& Family Law, Vol. 32, n 3, September 2010, pp. 237-245; ID., “Ante-nuptial contracts after Radmacher: an impermissible gloss?”, Vol. 33, no 1, March 2011, pp. 14-24; S.GASPAR LeRA, "Los acuerdos prematrimoniales en el Derecho inglés”, Indret, 3/2012, disponible en http://www.indret.com/pdf/913_es.pdf (consultado el 19 de diciembre de 2018); B.HALE., «Equality and autonomy in family law», Journal of Social Welfare \& Family Law, Vol. 33, n 1, March 2011, pp. 3-14;. A.MeEHAN, "Radmacher: What practitioners need from the Supreme Court", Family Law, págs. 253-258; S. THOMPson, "Radmacher (formerly Granatino) v. Granatino [2010] UKSC 42", Journal of Social Welfare \& Family Law, Vol. 33, n 1, March 2011, pp 61-70; J.M. SHERPE, "Los acuerdos prematrimoniales en Inglaterra y Gales tras Radmacher v. Granatino", Indret, Barcelona, 2012, pp. 1- 24.

48 En la section 9 letra se recoge que es necesario que ambas partes cuenten con asesoramiento legal independiente. Sin embargo, en la misma section en la letra b, se matiza este requisito y se considera que una parte ha sido "asesorada" cuando 1) ha contado con tiempo suficiente para contratar a un abogado, recibir el asesoramiento y poder considerarlo; 2) el otro futuro cónyuge ya cuenta con un abogado y bien la otra parte se puede pagar uno propio o que la otra parte se lo pague. Para un estudio más detallado del UPMAA 2012 vid. I. ANTÓN JuÁrez, “Acuerdos prematrimoniales: Ley...”, pp. 16 y ss; Ma . D. CERVILla Garzón, “Acuerdos prematrimoniales y matrimoniales en el actual derecho de los Estados unidos", Revista de Derecho Civil, Vol IV, núm. 2, 2017, pp. 17 y ss.

49 Se han referido a este particular A. RodRiguez Guití́n, Los pactos de pre-Ruptura..., p. 147 y anteriormente vid. A. Serrano de Nicolás, "Los pactos en..., p. 72.

50 A nuestro parecer más dudas sobre la validez del acuerdo se podrían plantear en el caso del Derecho civil catalán. Esto es así porque en el art. 231.20 de la Ley 25/2010, de 29 de julio, del libro segundo del Código Civil de Cataluña, relativo a la persona y la familia se recoge que "el cónyuge que pretenda hacer valer un pacto en previsión de una ruptura matrimonial tiene la carga de acreditar que la otra parte disponía, en el momento de firmarlo, de información suficiente sobre su patrimonio, sus ingresos y sus expectativas económicas, siempre y cuando esta información fuese relevante con relación al contenido del pacto". No obstante, hay doctrina que señala que la inexistencia de información en el Derecho civil catalán no implica que el acuerdo sea nulo sino la consecuencia sería que no podría ejecutarse. Esta visión la sostiene A. Rodríguez GutTían, Los pactos de pre-Ruptura ..., p. 160. Para un estudio más en profundidad sobre este art. 231.20 vid. J. SolÉ Feliú,”Comentario al article 231-20 del Codi Civil de Catalunya”, en J. Egea i Fernández/ J. Ferrer i Riba/ E. Farnós i Amorós (Coods.), Atelier, Barcelona, 2014.

51 Vid. L. A. Anguita Villanueva, “Acuerdos prematrimoniales: del modelo de los EE.UU. a la realidad española”, J. Rams Ablesa/C. de Amunategui/ E. Serrano/ L.A Anguita, Autonomía de la voluntad y negocios jurídicos de familia, Dykinson, Madrid, 2010, pp. 275 y ss. 
1) La información financiera debe prestarse antes de la celebración del acuerdo. El deber de informarse mutuamente sobre los patrimonios no puede diferirse al momento que los futuros cónyuges deseen ${ }^{52}$. Como el objetivo de este aspecto es que se pueda demostrar un consentimiento informado en el momento de la celebración del acuerdo, el deber de información debe realizarse antes de la firma del acuerdo obligatoriamente.

2) La información sobre el patrimonio de los cónyuges no debe ser exhaustiva. La información que se preste tiene que permitir que la otra parte se forje una idea aproximada del patrimonio e ingresos de su futuro cónyuge ${ }^{53}$. Lo aconsejable sería presentar un inventario donde se recojan los activos y pasivos del patrimonio junto con los ingresos presentes y también sobre expectativas de ingresos futuros, ad ex. un bonus que se prevé percibir en un corto período de tiempo. No se deben incluir ingresos hipotéticos, se debería especificar de dónde proceden los ingresos, indicando su carácter ordinario o extraordinario. Otra opción, diferente a la del inventario, sería la de adjuntar al acuerdo prematrimonial un documento donde ambos cónyuges reconocen que están informados sobre la información financiera del otro ${ }^{54}$. Más dudoso sería que fuera válido un documento donde se renuncia a recibir información financiera. El legislador catalán no recoge nada al respecto ${ }^{55}$. Sin embargo, tal renuncia sí que se recoge en la section 9 en su letra d del UPMAA 2012. En definitiva, lo importante es que con independencia de la vía que se utilice para informar se transmita una información veraz, no completa pero sí suficiente, que en caso de desacuerdo futuro, permite al cónyuge interesado probar que la información patrimonial que se transmitió fue acorde con la buena fe contractual. Principio también presente en los acuerdos prematrimoniales.

3) La carga de probar de que ha existido información financiera recae sobre el cónyuge que quiere demostrar que ha existido tal información. Este cónyuge será normalmente el que persiga la ejecución del acuerdo prematrimonial. El otro cónyuge, al que se la ha supuestamente prestado la información, no tiene que probar que no se le informó. Así, se recoge en el precepto 7.04 (5) de los ALI Principles.

4) La celebración del pacto ante notario no permite presumir que ha existido información financiera recíproca. La doctrina señala que la intervención del notario no implica que se ha prestado información financiera ${ }^{56}$. En el Derecho civil catalán, el notario tiene la obligación de advertir a los cónyuges de que se deben informar recíprocamente, pero no que deba proporcionar la información el propio notario ${ }^{57}$. Esta visión podría trasladarse al Derecho civil común y considerar que el hecho de que el pacto prenupcial se haya formalizado ante notario no implica en ningún caso la presunción de que las partes se han informado recíprocamente sobre sus patrimonios.

\section{Requisito 4: el contenido del acuerdo no puede dañar el orden público, la moral ni la ley}

\section{A) Determinación del Derecho aplicable al fondo del acuerdo prematrimonial}

26. Comenzando con la perspectiva internacional privatista, si el acuerdo prematrimonial contiene un elemento extranjero es necesario antes de nada determinar el Derecho aplicable a ese pacto desde

52 A. Rodriguez Guitián, Los pactos de Pre-Ruptura ..., p. 154.

53 Esta visión puede verse en el asunto Vechio vs. Vechio (143 So.2d.17) que fue resuelto por el Tribunal Supremo de Florida en 1962. En este caso, uno de los primeros sobre acuerdos prematrimoniales en USA, El tribunal entiende que con una información aproximada sobre el patrimonio del marido era suficiente. Para un comentario sobre esta resolución vid. M ${ }^{\mathrm{a}}$.D. Cervilla Garzón, Los acuerdos prematrimoniales..., pp. 58-60.

54 Sobre este particular vid. A. Rodriguez Guitián, Los pactos de pre-Ruptura ..., p. 160; Vid también, A. LAmArCA i MarQUÉS, "Els pactes en previsió de crisi matrimonial i de la convivéncia", en Institut de Dret Privat Europeu i Comparat de la Universitat de Girona (ed.), Qüestions actuals del dret català de la persona i de la familia, Materials de les Dissetenes Jornades de Dret catalá a Tossa, Documentia Universitaria, Girona, 2013, p. 465.

55 A. Rodriguez Guitián, Los pactos de Pre-Ruptura ..., p. 161.

56 Ibidem, pp. 158-159;

57 J. SolÉ Feliú,"Comentario al article...", p. 152. 
un punto de vista material o de fondo. Siguiendo con el razonamiento expuesto anteriormente, si el pacto se ha celebrado antes de que el RREM sea de aplicación (29 de enero de 2019) será necesario determinar el Derecho aplicable conforme a la norma de conflicto prevista en el ordenamiento español para ello, el art. 9.3 $\mathrm{CC}^{58}$. Sin embargo, si el acuerdo prematrimonial internacional es posterior a esa fecha será de aplicación el art. $27 \mathrm{~g}$ ) RREM. Este precepto del RREM señala que es la Ley aplicable al régimen económico matrimonial la que rige la validez material de los acuerdos celebrados entre los futuros cónyuges.

27. El propio texto del acuerdo prematrimonial podría contener una elección de Ley. El legislador europeo permite que dicha elección se pueda hacer en un acuerdo antes del matrimonio, en el momento de su celebración o durante el mismo (considerando 45 RREM), pudiendo ser la elección de ley expresa o tácita ${ }^{59}$. A nuestro juicio, la opción más recomendable es que la elección de ley se realice de forma expresa y se incluya en el articulado del acuerdo prematrimonial. Esto evitaría cualquier duda o especulación sobre la Ley aplicable no sólo al régimen económico matrimonial sino al propio pacto prematrimonial. No obstante, también sería posible que dicha elección de ley se realizara en un documento privado o público que no es el acuerdo prematrimonial propiamente dicho. Lo importante a efectos de determinar la validez de la elección de ley es que se cumplan los requisitos de forma y de fondo que el RREM exige (arts. 22, 23 y 24 RREM).

El art. 22 RREM señala las leyes entre las cuales los cónyuges o futuros cónyuges podrían elegir. La autonomía de la voluntad conflictual que recoge el RREM es limitada, ya que circunscribe esa libertad de elección a una serie de leyes concretas. En particular, los futuros cónyuges podrían elegir entre $^{60}:$ 1) la ley de la residencia habitual común de los futuros cónyuges al momento de la celebración del acuerdo (art. 22.1.a); 2) la ley de la residencia habitual de uno de los futuros cónyuges al momento de la celebración del acuerdo (art. 22.1.a); 3) la ley de la nacionalidad de cualquier de los futuros cónyuges al momento de celebración del acuerdo (art. 22.1.b).

Los futuros cónyuges podrían en virtud del art. 22.2 RREM modificar la elección de ley realizada en un primer momento. Este cambio realizado durante el matrimonio, sólo surtirá efectos en el futuro, salvo acuerdo contrario de los cónyuges. En ningún caso, dicho cambio aunque tuviera efectos retroactivos podrá afectar de manera negativa a los derechos adquiridos por terceros conforme a la ley que los cónyuges eligieron en un primer momento ${ }^{61}$.

En relación a los requisitos de forma, el art. 23 RREM, señala que el acuerdo de elección de ley debe realizarse por escrito, estar fechado y firmado por ambos cónyuges. El propio RREM en su art. 23.1 detalla que se considera en forma escrita "cualquier comunicación efectuada por medios electrónicos que proporcione un registro duradero del acuerdo". El hecho de que se exija la forma escrita no implica que no se pueda hacer una elección de ley tácita en el acuerdo celebrado por los futuros contrayentes. Esta elección tácita debe permitir que los cónyuges sepan cual es la concreta ley aplicable a su régimen económico matrimonial desde el momento que se otorga el pacto ${ }^{62}$. Así, ad ex., en el acuerdo prematrimonial, se podría señalar que la ley aplicable al régimen económico matrimonial será la de la residencia habitual común tras la celebración del matrimonio. No señalan de forma expresa cuál es esa Ley, pero los cónyuges saben perfectamente dónde van a residir tras la celebración del enlace.

58 Sobre el art. 9.3 CC y los acuerdos prematrimoniales vid para un mayor detalle I. ANTÓN JUÁREZ, "Los acuerdos prematrimoniales...", pp. 66-74; B. AÑoveros TerradAs, “Los pactos prematrimoniales...", pp. 462-469.

59 Per alia, J. Rodríguez Rodrigo, “Régimen económico matrimonial...”, pp. 198-199.

60 Es interesante tener en cuenta que si el acuerdo prematrimonial internacional fuera realizado por una pareja de hecho, tendrían una ley aplicable más donde elegir, la ley conforme a la cual la pareja ha sido creada. Las parejas de hecho cuentan con un reglamento europeo propio, se les aplica el Reglamento Sin embargo, en el caso de los matrimonios, el RREM no recoge como punto de conexión la ley del país donde se celebró el matrimonio. A pesar de que este los tribunales del lugar donde se ha celebrado el matrimonio pueden ser elegidos para resolver las posibles controversias que pudieran surgir en torno a las cuestiones relativas al régimen económico matrimonial de los cónyuges o futuros cónyuges. Vid. críticas sobre este particular en la doctrina, en J. Rodríguez Rodrigo, "Régimen económico matrimonial...", p. 197 y S. Marino, "Strengthening the European civil judicial cooperation: the patrimonial effects of family relationships", $C D T, \mathrm{n}^{\circ}$ 9, vol. 1, 2017, p. 277.

${ }_{61}$ Para un mayor detalle sobre esta cuestión vid. L. RADEMACHER, "Changing the past: retroactice choice of law and the protection of third parties in the European regulation on patrimonial consequences of marriages and registered partnerships", $C D T$, vol. $10, \mathrm{n}^{\circ} 1$, pp. 7-18.

62 J. Rodríguez Rodrigo, “Régimen económico matrimonial...”, p. 199. 
El art. 23.2 RREM señala que es necesario tener en cuenta no sólo los requisitos formales que señala el Reglamento sino también todas aquellas formalidades que se recojan en la Ley del país donde los cónyuges tengan su residencia habitual en el momento de la celebración del acuerdo. En el supuesto de que la los cónyuges tengan su residencia habitual en diferentes Estados miembros al momento de celebración del acuerdo y dichas legislaciones exigen requisitos formales diferentes, el pacto de elección de ley conforme al RREM será válido formalmente si se tiene en cuenta cualquiera de esas leyes (art. 23.3). No hace que prevalezca la más exigente, por ejemplo. Si los futuros cónyuges, tienen su residencia habitual en diferentes países al momento de la celebración del acuerdo, uno en un Estado miembro y el otro no, sólo se exige el acople a los requisitos formales respecto del ordenamiento del país que pertenece al RREM, no es necesario seguir los requisitos formales del ordenamiento del Estado que no es parte. Este aspecto resulta un tanto contradictorio, teniendo en cuenta la aplicación universal del RREM $^{63}$. El art. 20 RREM señala que es indiferente que la Ley aplicable a la que lleven las normas de conflicto del Reglamento pertenezcan a un Estado miembro o no.

Respecto de los requisitos de fondo, un pacto de elección de ley se considerado válido desde un punto de vista material si es acorde con la Ley de algunos de los Estados que señala el citado art. 22 RREM (art. 24.1). Como ya se estudió, la ley que rige la capacidad de los futuros cónyuges es la que se determina mediante art. $9.1 \mathrm{CC}$. Norma de conflicto aplicable cuando la validez material del acuerdo de elección de ley es apreciada por un juez español. En el caso del consentimiento, éste se rige por la Ley elegida por las partes (art. 24.2). A esta regla general sería posible presentarle una excepción. Cuando uno de los contrayentes quiera probar que no prestó su consentimiento puede invocar la ley de su residencia habitual al momento de presentar la demanda, siempre que de las circunstancias del caso concreto se pueda apreciar que su conducta no puede analizarse en atención a la ley elegida por los cónyuges (art. 24.2) $)^{64}$.

28. Si los cónyuges no han elegido de forma expresa o tácita la Ley aplicable a su régimen económico matrimonial entraran en juego los puntos de conexión subsidiarios que se recogen en el art. 26 RREM. Estos puntos de conexión ordenados en cascada serían los siguientes: 1) La Ley del Estado de la primera residencia habitual común de los cónyuges tras la celebración del matrimonio (art. 26.1.a.); 2) La Ley del Estado de la nacionalidad común de los cónyuges en el momento de la celebración del matrimonio(art- 26.1.b.); 3) La Ley del Estado con la que los cónyuges tengan la conexión más estrecha en el momento de la celebración del matrimonio, teniendo presente todas las circunstancias (art. 26.1.c.).

El mismo art. 26.3 RREM recoge una cláusula de excepción o cláusula de escape al punto de conexión recogido en el art. 26.1.a RREM. El juez competente puede dejar de aplicar el primer punto de conexión relativo a la primera residencia habitual común de los cónyuges tras la celebración del matrimonio cuando se demuestre que existe otro Estado con mayor conexión. Así puede probarse una mayor conexión con ese otro Estado cuando la última residencia habitual común de los cónyuges estuvo ahí, su duración fue considerablemente mayor que en el Estado que señala el art. 26.1 en su letra a y además se puede demostrar que ambos cónyuges se basaron en la ley de ese Estado para organizar sus relaciones patrimoniales. No obstante, hay que tener en cuenta que esta cláusula de escape no es de aplicación cuando los cónyuges hayan otorgado capitulaciones matrimoniales o pacto similar con anterioridad al establecimiento de su última residencia habitual común. De este modo, esta cláusula de escape va a operar cuando no haya habido elección Ley, ni expresa ni tácita. Esto confirma que la existencia de esas capitulaciones matrimoniales celebradas con anterioridad al establecimiento de la última residencia habitual común de los cónyuges a las que se refiere el art. 26 RREM en su último apartado no deben contener elección de ley alguna, ya que si así fuera estaríamos en el art. 22 y no en el art. $26^{65}$.

29. Por lo tanto, en resumen, la Ley aplicable a la validez material de un acuerdo prematrimonial internacional será la Ley elegida por los futuros cónyuges en atención a los arts. 22 a 24 RREM. Las

\footnotetext{
63 J. Rodríguez Rodrigo, "Régimen económico matrimonial...”, p. 200.

64 Ibidem, pp. 200-201.

65 J. Rodríguez Rodrigo, "Régimen económico matrimonial...”, p 205.
} 
Leyes entre las que podrían elegir los futuros contrayentes son bien la Ley de su residencia habitual común o la de uno de los contrayentes al momento de celebración del acuerdo o la Ley de la nacionalidad de cualquiera de ellos. En el caso de que los futuros cónyuges no hayan elegido la Ley aplicable a su régimen económico matrimonial o ésta elección no resulte válida conforme al RREM se deberá recurrir para determinar la Ley aplicable al régimen económico matrimonial, y por ende, a la validez material del acuerdo prematrimonial a los puntos de conexión subsidiarios recogidos en el art. 26 RREM.

No obstante, conviene recordar que aunque lo deseable es que una única Ley determine la validez material del acuerdo prematrimonial, somos conscientes de que no en todos los casos va a ser posible. Ello va a depender del contenido concreto del acuerdo en el que nos encontremos. Así, cuanto más heterogéneo sea el acuerdo, más difícil va ser que se utilice un único instrumento legal internacional para determinar su derecho aplicable. Esto es así porque habrá cláusulas que van a escapar del ámbito de aplicación del RREM ${ }^{66}$. Por lo tanto, las normas del conflicto del RREM no se van a poder utilizar. $A d$ ex. esto sucede con las cláusulas en las que se renuncia a la prestación compensatoria. Desde un punto de vista conflictual, la prestación compensatoria se considera una cuestión alimenticia, así se aplicará a la determinación de su Ley aplicable el Protocolo de la Haya, de 23 de noviembre de 2007, sobre Ley aplicable a las obligaciones alimenticias ${ }^{67}$ (en adelante, PH 2007). La Ley que determine este Protocolo será la que precise si una renuncia a una prestación compensatoria es válida o no lo es ${ }^{68}$. De la misma forma sucede con la ley que rige el divorcio. Los cónyuges podría elegir en el acuerdo prematrimonial en atención a los arts. 5 a 7 del Reglamento UE $n^{\circ}$ 1259/2010 del Consejo, de 20 de diciembre de 2010, por el que se establece una cooperación reforzada en el ámbito de la ley aplicable al divorcio y a la separación judicial (en adelante, R. Roma III) la ley que debe determinar su divorcio o separación judicial. De este modo, tampoco se podría aplicar el RREM para determinar los efectos personales del patrimonio. En este caso el Derecho aplicable debe regirse por el art. 9.2 CC. Por lo tanto, uno de los aspectos más interesantes a la par que problemáticos que plantean los acuerdos prematrimoniales internacionales es su acople en el supuesto de hecho de una norma de conflicto. Que se apliquen una o varias normas de conflicto dependerá de lo variado que sea su clausulado. Cuanto más variado, más normas de conflicto se tendrán que tener en cuenta. Esto hace que la tarea del juez se complique por dos motivos:

1) deberá aplicar los diferentes instrumentos legales internacionales de forma coordinada y con coherencia (en nota a pie:sobre este particular vid. ad. ex. A. Bonomi, "The interaction among the future EU instruments on matrimonial property, registered partnerships and successions", Yearbook of Private International Law, vol. 13, 2011, pp. 217-231;B. Campuzano Díaz, The Coordination of the EU Regulations on divorce and legal separation with the proposal on Matrimonial Property Regimes, Yearbook of Private International Law, vol 13, 2011, pp. 233-253).

2) la aplicación de diferentes normas de conflicto puede dar lugar a que se apliquen Leyes de diferentes ordenamientos a un mismo acuerdo prematrimonial.

66 El RREM excluye de su ámbito de aplicación material las obligaciones de alimentos. Así se recoge en su considerando 22 y también en su art. 1.2. Esta exclusión de los alimentos que se realiza en el RREM puede no sorprender tanto a los ordenamientos que se integran en el Civil Law. Esto es así porque es un aspecto que puede entenderse como una carga del matrimonio como también un deber de asistencia entre los esposos. Sin embargo, no sucede así en los ordenamientos del Common Law. En estos países no está clara la distinción entre la propiedad relativa al matrimonio y alimentos. Vid. sobre este particular, I. VISMARA, "The EU proposal on matrimonial property regimes. Some general remarks", Yearbook of Private International Law, vol. 13, 2011 , p. 203.

67 DO núm. L 177, de 4 de julio de 2008.

68 El ámbito material del Protocolo de la Haya de 2007 es muy amplio, en atención a este instrumento legal internacional "por obligaciones alimenticias" se deben entender los alimentos en toda su extensión (art. $142 \mathrm{CC}$ ), los auxilios necesarios para la vida (art. 143.II CC) y también toda prestación compensatoria que surge por ley tras el divorcio (art. 97 CC). Para un mayor detalle sobre la determinación de la Ley aplicable a las obligaciones alimenticias vid. ad ex. J. CARrascosa GonzÁlez, "Alimentos", en A.L. Calvo Caravaca/J. Carrascosa González, Derecho Internacional Privado, Vol. II, decimoactava edición, Comares, Granada, 2018, pp. 550-562; E. Castellanos Ruiz, Aspectos internacionales y transfronterizos, Tirant lo Blanch, Valencia, 2018, pp. 69-109; Ma . A. Rodríguez VÁzQuEz, "La regulación del Reglamento 4/2009 en materia de obligaciones de alimentos: competencia judicial internacional, Ley aplicable y reconocimiento y ejecución de sentencias”, REEI, 19, 2010, pp. 18-25. 
Este escenario podría evitarse en cierta medida cuando los cónyuges hacen uso de la autonomía de la voluntad conflictual en atención a los Reglamentos europeos en materia de familia. (en nota a pie, M. Vinaixa Miquel, "La autonomía de la voluntad en los recientes reglamentos UE en materia de régimenes económico matrimoniales (2016/1103) y efectos patrimoniales de las uniones registradas (2016/1104)", El orden público interno, europeo e internacional civil. Acto en homenaje a la Dra. Núria Bouza Vidal, catedràtica de Derecho internacional privado, Indret, 2017, p. 302 y ss. )

30. Para terminar, sería interesante pensar en el siguiente ejemplo que podría darse en un futuro cercano: italiana y español celebran un acuerdo prematrimonial en febrero de 2019. Ambos celebran este acuerdo en España ante notario, ya que va a ser este su país de residencia tras la celebración del matrimonio. En el acuerdo prematrimonial, se recoge que el régimen económico matrimonial es el régimen de separación de bienes y ambos renuncian de forma recíproca a cualquier tipo de pensión compensatoria que por ley les pudiera corresponder en caso de divorcio. Tras varios años casados, el marido interpone demanda de divorcio ante tribunales españoles. Éste no solo solicita el divorcio, también una pensión compensatoria en atención al art. $97 \mathrm{CC}$. La esposa se niega y hace valer ante el juez el acuerdo prematrimonial que firmaron hace escasamente dos años. El juez para saber si dicho pacto es válido y de plena aplicación debe saber la ley aplicable a dicho acuerdo prematrimonial.

En particular, deberá determinar la Ley aplicable a la forma y al fondo. En cuanto a la validez material, lo primero que hay que determinar es si en el propio acuerdo prematrimonial se recoge por qué ley se rige y determinar si dicha elección es válida. Si no se señala nada, en atención al art. 27 g. RREM, la Ley aplicable al régimen económico matrimonial es la que determina también la validez material del acuerdo. Es importante saber si en el acuerdo se determina la Ley aplicable al régimen económico matrimonial en atención a los arts. 22, 23 y 24 RREM de forma tácita o expresa. Si no se señala nada al respecto o resulta inválido, hay que acudir a los puntos de conexión del art. 26 RREM. Así, la Ley aplicable a este acuerdo prematrimonial, será en atención al art. 26.1.a la Ley española, ya que es la Ley del Estado donde los cónyuges establecieron su primera residencia habitual común tras la celebración del matrimonio. Sin embargo, esta norma de conflicto del RREM no puede aplicarse para señalar si la renuncia a la pensión compensatoria es válida. Para ello, se debe atender a las normas de conflicto del PH 2007. El art. 3 PH 2007, norma de conflicto aplicable en defecto de elección de ley, señala la ley aplicable a las obligaciones de alimentos será la Ley de la residencia habitual del acreedor de alimentos. En este caso, el acreedor sería el esposo. Éste tiene su residencia habitual en España. Así, será el Derecho español, en concreto el art. $97 \mathrm{CC}$, el derecho aplicable para determinar si esa renuncia realizada en el acuerdo prematrimonial es válida o no lo es.

De la misma forma sucede con la ley que rige el divorcio. Los cónyuges podría elegir en el acuerdo prematrimonial en atención a los arts. 5 a 7 del Reglamento UE $n^{\circ}$ 1259/2010 del Consejo, de 20 de diciembre de 2010, por el que se establece una cooperación reforzada en el ámbito de la ley aplicable al divorcio y a la separación judicial (en adelante, R. Roma III) la ley que debe determinar su divorcio o separación judicial. De este modo, tampoco se podría aplicar el RREM para determinar los efectos personales del patrimonio. En este caso el Derecho aplicable debe regirse por el art. 9.2 CC. Por lo tanto, uno de los aspectos más interesantes a la par que problemáticos que plantean los acuerdos prematrimoniales internacionales es su acople en el supuesto de hecho de una norma de conflicto. Que se apliquen una o varias normas de conflicto dependerá de lo variado que sea su clausulado. Cuanto más variado, más normas de conflicto se tendrán que tener en cuenta. Esto hace que la tarea del juez se complique por dos motivos:

1) deberá aplicar los diferentes instrumentos legales internacionales de forma coordinada y con coherencia $^{69}$

2) la aplicación de diferentes normas de conflicto puede dar lugar a que se apliquen Leyes de diferentes ordenamientos a un mismo acuerdo prematrimonial.

69 Sobre este particular vid. ad. ex. A. BonOMI, "The interaction among the future EU instruments on matrimonial property, registered partnerships and successions", Yearbook of Private International Law, vol. 13, 2011, pp. 217-231; B. CAMPUZANo DíAz, The Coordination of the EU Regulations on divorce and legal separation with the proposal on Matrimonial Property Regimes, Yearbook of Private International Law, vol 13, 2011, pp. 233-253. 
Este escenario podría evitarse en cierta medida cuando los cónyuges hacen uso de la autonomía de la voluntad conflictual en atención a los Reglamentos europeos en materia de familia ${ }^{70}$.

\section{B) El contenido del acuerdo prematrimonial desde el Derecho material español: Limites generales a la autonomía de la voluntad: el orden público, la ley y la moral}

31. Como ya hemos señalado, una característica esencial de los acuerdos prematrimoniales en previsión de separación o divorcio es que pueden contener cláusulas de diversa índole. En otras palabras, el contenido del acuerdo prematrimonial que se celebra con el fin de que los cónyuges determinen los efectos de su ruptura puede ser muy heterogéneo. Esto es así porque en atención al Derecho español los cónyuges disponen de una amplia libertad. En base a su autonomía de la voluntad, los futuros cónyuges podrían incluir cualquier cláusula con el único límite general que se aplica al resto de los contratos, el art. 1255 CC. Así, de este modo, a priori en un acuerdo prematrimonial que se rige por el Derecho español se podrían incluir todo tipo de aspectos económicos, pero también personales siempre que ninguno de ellos menoscabe el orden público, la ley o la moral.

32. Así, partiendo de la base de la amplia autonomía de la voluntad de la que disponen los futuros cónyuges en atención al Derecho material español, sería necesario señalar los límites que se podrían encontrar. De este modo, en atención a lo que se va a exponer, el asesor o abogado que redacte un acuerdo prematrimonial en atención al Derecho español debería tener en cuenta qué contenido podría menoscabar el orden público, la moral o la ley con el fin bien de evitar su inclusión en el acuerdo o en el caso de incluirse sería necesario que informara a las partes de que un futuro podría plantear problemas de validez o de eficacia del acuerdo ${ }^{71}$.

33. En relación al orden público, las cláusulas que se deberían evitar serían todas aquellas que pueden ser contrarias $\mathrm{a}^{72}: 1$ ) la protección de la familia; 2) la protección de los hijos; 3)la protección de los terceros; 4) a los Derechos Fundamentales de los propios cónyuges, como el Derecho a la igualdad o la libre desarrollo de la personalidad.

En particular, en relación a la protección de los hijos, es necesario señalar que en virtud del art. 39.2 de la Constitución española, concretado en el art. $90 \mathrm{CC}$, no es posible celebrar un acuerdo prematrimonial que bien de forma directa o indirecta perjudique a los hijos. Y en el caso de que así fuera, el acuerdo será considerado nulo. Tales cláusulas podrían ser aquellas que privan a uno de los cónyuges del derecho de visita, se renuncia al ejercicio de la patria potestad ${ }^{73}$ o se excluye la pensión de alimentos a favor de los hijos ${ }^{74} \mathrm{o}$ incluso aquellos que provocan que los hijos tengan lo justo para sobrevivir mientras que es posible ofrecerles un mayor bienestar económico debido a las posibilidades económicas de los progenitores ${ }^{75}$. En definitiva, un acuerdo prematrimonial en ningún caso va a ser válido si no vela por el interés superior del menor. En nuestra opinión, sobre los hijos se pueden adoptar previsiones en un acuerdo prematrimonial, la autonomía de la voluntad de los cónyuges también se puede extender a los hijos ${ }^{76}$. No obstante, los cónyuges deben ser muy respetuosos con los intereses

70 M. Vinaixa Miquel, "La autonomía de la voluntad en los recientes reglamentos UE en materia de régimenes económico matrimoniales (2016/1103) y efectos patrimoniales de las uniones registradas (2016/1104)", El orden público interno, europeo e internacional civil. Acto en homenaje a la Dra. Núria Bouza Vidal, catedràtica de Derecho internacional privado, Indret, 2017, p. 302 y ss.

71 Hay doctrina que entiende que esta labor de asesoramiento y de control de legalidad del acuerdo prematrimonial lo puede realizar el notario, vid. sobre este particular A . RodRIGUEz GuITIÁN, Los pactos de Pre-Ruptura ..., pp. 179-183.

72 A. Rodriguez Guitián, Los pactos de Pre-Ruptura ..., p. 184-189.

73 V. Moreno Velasco, Autonomía de la voluntad y crisis matrimoniales, Thomson Reuters Aranzadi, Cizur Menor (Navarra), 2013, p. 83 .

$74 \mathrm{El}$ art. $155 \mathrm{CC}$ no permite que los progenitores renuncien a la pensión de alimentos que por ministerio de la ley corresponden a los hijos.

75 Estas previsiones podrían ir en contra de lo dispuesto en el art. 146 CC. Este artículo señala que "la cuantía de los alimentos será proporcionada al caudal o medios de quien los da y a las necesidades de quien los recibe". Esto no quiere decir que los cónyuges no puedan acordar la pensión de alimentos que en el caso de ruptura abonarían a sus hijos, pueden hacerlo pero siempre teniendo en cuenta que ésta debe ser acorde con el poder adquisitivo de quién la da y en atención a las necesidades de los hijos.

76 No toda la doctrina opina así, hay autores que consideran que las previsiones relativas a los hijos no deben incluirse 
de los hijos, intentando superponerlos a los suyos propios y asegurando en todo caso su bienestar. En ningún caso hay que olvidar que cualquier previsión que hagan los cónyuges sobre los hijos menores necesita de la aprobación judicial.

Respecto a la protección de los terceros, hay que tener en cuenta que la renuncia a determinados derechos como puede ser una pensión compensatoria puede dar lugar a que la situación económica en la que queda uno de los cónyuges tras la ruptura ocasione efectos negativos en terceros. Esos terceros perjudicados por el pacto podrían ser familiares de ese cónyuge que deben prestar alimentos debido a la precaria situación en la que queda, piénsese en los propios hijos, o incluso en los padres o hermanos ${ }^{77}$. Otros perjudicados también podrían ser los acreedores de ese cónyuge. Estos terceros perjudicados podrían iniciar una acción de nulidad del acuerdo prematrimonial amparándose en que el mismo menoscaba el orden público por vulnerar el art. 9.3 CE, ya que el Estado debe garantizar que los negocios jurídicos no menoscaban la seguridad jurídica perjudicando a terceros ${ }^{78}$. Otro argumento para intentar dejar sin efecto el acuerdo puede venir de la mano del art. 6.2 CC, en el que se recoge que "La exclusión voluntaria de la ley aplicable y la renuncia a los derechos en ella reconocidos sólo serán válidas cuando no contrarien el interés o el orden público ni perjudiquen a terceros".

En relación a la vulneración de los derechos fundamentales de los cónyuges, la doctrina ha señalado que dicha vulneración puede ser más probable que existe si se pacta sobre aspectos personales más que si se el pacto versa sobre aspectos patrimoniales ${ }^{79}$. Así, ad ex. un acuerdo prematrimonial en el que se prohíba a uno de los cónyuges a solicitar el divorcio o que prohíba o se obligue a residir en un determinado lugar ${ }^{80}$ pueden menoscabar el orden público por vulnerar el derecho al libre desarrollo de la personalidad o el derecho a divorciarse.

Un derecho que se tiene muy en cuenta por los tribunales cuando deben revisar los acuerdos prematrimoniales en previsión de ruptura es la incidencia que estos presentan en el derecho a igualdad de los cónyuges. Derecho recogido en los arts. 14 y 32 de la Constitución española y que se detalla en los arts. 66 y 1328 CC. En este último precepto se señala que "será nula cualquier estipulación contraria a las Leyes o a las buenas costumbres o limitativa de la igualdad de derechos que corresponda a cada cónyuge". La doctrina civilista ${ }^{81} \mathrm{y}$ también los tribunales han señalado que el derecho de igualdad se respeta cuando en el acuerdo prematrimonial no existe sumisión o subordinación de un cónyuge frente al otro. A nuestro juicio, el derecho a la igualdad de los cónyuges en los acuerdos en previsión de ruptura no puede entenderse como un igualitarismo absoluto que no permita a los cónyuges organizar su ruptura como ellos mejor consideren $^{82}$. Tampoco se vulneraría el derecho de igualdad cuando no hay reciprocidad en las renuncias o limitaciones a derechos se establecen a determinados derechos en el acuerdo por los cónyuges ${ }^{83}$. En nuestra opinión, para saber si un acuerdo vulnera el derecho a la igualdad no basta con comprobar si las disposiciones que se realizan sobre el acuerdo son recíprocas o no ${ }^{84}$. Se debe comprobar y sopesar en global, en atención a todas las disposiciones del acuerdo teniendo y muy en cuenta las circunstancias patrimoniales de los cónyuges en el momento de la firma y también en el momento de la ejecución ${ }^{85}$.

dentro de la autonomía de la voluntad de los cónyuges debido a que son normas imperativas que buscan salvaguardar el interés superior del menor, E. Roca TRÍAs, “Autonomía, crisis matrimonial...”, pp. 2113-2114.

77 Esa obligación de prestar alimentos nacería del art. $144 \mathrm{CC}$, donde se señala que también existe obligación de prestar alimentos no sólo al cónyuge o a los hijos, también a los ascendientes e incluso a los hermanos.

78 Vid. V. Moreno Velasco, Autonomía de la ..., p 35;A . Rodriguez Guitián, Los pactos de Pre-Ruptura ..., p. 186.

79 A . Rodriguez Guití́n, Los pactos de Pre-Ruptura ..., pp. 186-187.

80 Ibidem, p. 187.

81 Idem.

82 En este sentido, vid. también, A. Rodriguez Guitı́́n, Los pactos de Pre-Ruptura ..., p. 200

83 Ibidem, pp. 202-207.

${ }^{84}$ En el Derecho civil de Cataluña no puede entenderse así, ya que en el apartado 3 del art. 231.20 de la Ley 25/2010, de 29 de julio, del libro segundo del Código Civil de Cataluña, relativo a la persona y la familia se recoge que "los pactos de exclusión o limitación de derechos deben tener carácter recíproco y precisar con claridad los derechos que limitan o a los que se renuncia".

85 Prueba de ello es la SAP Madrid de 27 de febrero de 2007 (JUR 2007/151411), donde se estima válido un acuerdo celebrado poco antes del enlace mediante el cual la esposa renuncia al derecho de uso de la vivienda familiar. El tribunal en el FJ $5^{\circ}$ considera que este pacto, aunque recoge una renuncia unilateral no atenta contra el derecho de igualdad debido a que a la mujer se la compensa. Esto es así porque a cambio de la renuncia recibe la propiedad de dos viviendas. 
34. Respecto a la vulneración de la Ley, no será válido un acuerdo prematrimonial que transgreda normas imperativas del ordenamiento jurídico español. La doctrina civilista ha discutido y sigue discutiendo sobre qué debe entenderse por norma imperativa ${ }^{86}$. En aras de circunscribirnos al objeto del presente trabajo y no profundizar en materias que se pueden escapar del mismo, se puede señalar que como regla general es imperativa toda norma que contiene prohibiciones y que su transgresión implica la sanción de nulidad del negocio jurídico ${ }^{87}$. De este modo, un acuerdo prematrimonial que vulnera normas imperativas como las relativa a la constitución o extinción del vínculo matrimonial o las normas relativas al régimen económico matrimonial primario (arts. 1315-1324 CC) va a ser contrario a la Ley, y por ende, nulo. Así, ad ex., en un acuerdo entre cónyuges no se podría exigir requisitos adicionales de los que señala la ley para que el matrimonio sea considerado válido ni tampoco se pueden exigir más criterios que los que el ordenamiento español estipula para poder divorciarse. Este último caso podría darse si en el acuerdo se exige que para poder acceder al divorcio uno de los cónyuges debe pagar un indemnización al otro ${ }^{88}$.

A nuestro juicio más dudas plantea que se considere que las cláusulas sobre los deberes personales que nacen por razón del matrimonio (arts. 66-68 CC) pueda ser considerado en todo caso una vulneración de la Ley. Como ya sostuvimos en otro trabajo anterior ${ }^{89}$, la autonomía de la voluntad también debería incluir la posibilidad de que los cónyuges pacten sobre aspectos personales. Así, pactar sobre los deberes personales se debería permitir, extinguir los deberes personales no ${ }^{90}$. Así, en nuestra opinión, una cláusula que refuerce el deber de fidelidad no atentaría contra los arts. 66-68 CC. Sin embargo, otra en la que se excluye el deber de socorro mutuo sí.

35. En relación a la moral, este aspecto que puede limitar la autonomía de la voluntad en atención a los arts. 1255 y $1328 \mathrm{CC}$, en la actualidad no tiene demasiado recorrido para declarar nulo un acuerdo prematrimonial en previsión de ruptura ${ }^{91}$. Esto es así debido a que se trata de un concepto jurídico indeterminado que no tiene especial relevancia en la esfera patrimonial de los cónyuges ${ }^{92}$. Su relevancia quedaría relegada a la esfera personal de los cónyuges. Como ejemplo de cláusula que podría atentar contra la moral se podría señalar la de la ya citada SAP de Almería, de 17 de febrero de 2003, donde el tribunal considera que una cláusula que penaliza el cese de convivencia puede entenderse contraria a la moral y a las buenas costumbres ${ }^{93}$. Otro tipo de cláusulas que la doctrina civilista ha considerado contrarias a la moral serían aquellas que atribuyen bienes a uno a los cónyuges o entre sí a cambio de la realización de una conducta prohibida por el ordenamiento ${ }^{94}$.

\section{Requisito 5: análisis de las circunstancias al momento de la ejecución}

\section{A) Alteración sobrevenida de las circunstancias y grave perjuicio}

36. Desde una visión internacional privatista, y del RREM en particular, no se señala nada sobre la alteración sobrevenida de las circunstancias, hubiera sido deseable que se hubiera recogido pero

86 Vid. ad ex. L. Dítz-PicAzo, Comentario al art. 1255 del Código Civil, p. 431 y ss.

87 A. Rodriguez Guití́n, Los pactos de Pre-Ruptura ..., p. 188.

88 SAP de Almería, de 17 de febrero de 2003 (AC 2003\623), FJ $2^{\circ}$. Esta sentencia consideró nula una cláusula recogida en un acuerdo prematrimonial entre español y rusa donde se obligaba al marido a pagar a la esposa por cada día de matrimonio una cantidad dineraria en el caso de que la ruptura tuviera lugar. La AP consideró que esta cláusula que establecía la indemnización era realmente una cláusula penal. Su fijación implicaba penalizar el cese de convivencia lo cual va en contra del orden público matrimonial por considerarlo contrario a la moral, las buenas costumbres y la ética social. Por tanto, nula de acuerdo al art. $1328 \mathrm{CC}$. Para un mayor detalle sobre este tipo de cláusula vid. L.M. MARTíneZ VÁzquEZ DE CASTRo, "Pactos prematrimoniales, cláusulas penales y daños morales”, en Estudios Jurídicos en Homenaje al Profesor José María Miquel, Aranzadi, 2014, pp. 1863-1874.

89 I. Antón JuÁrez, “Acuerdos prematrimoniales: Ley...,", pp. 41-42.

90 Vid. A. J. Pérez Martín, Pactos prematrimoniales, capitulaciones matrimoniales, convenio regulador, procedimiento, Lex Nova, Valladolid, 2009, p. 92.

91 A. Rodriguez Guití́n, Los pactos de Pre-Ruptura ..., p. 189.

92 Vid. A. Cabanillas Sánchez, "Comentario al art. 1328..., p. 854.

93 AC 2003\623, FJ $2^{\circ}$

94 A. Cabanillas Sánchez, "Comentario al art. 1328 del Código Civil” en R. Bercovitz Cano/ L. Dízz Picazo/ C. Paz Ares/ P. Salvador Cordech (Dirs.), Comentario al Código Civil, Tomo II, 2a ed., Ministerio de Justicia, Madrid, 1993, pp. 605-606. 
no se hace. Por lo tanto, sobre este particular a nuestro juicio el juzgador debería tener presente la Ley aplicable al fondo del acuerdo y también como la aplicaría un operador jurídico de ese ordenamiento. Esto es importante cuando no hay coincidencia entre la Ley aplicable acuerdo y el ordenamiento al que pertenece el juez que conoce. La Ley que rige el acuerdo prematrimonial es importante porque le va a indicar al operador jurídico cómo se entienden en ese ordenamiento legal y jurisprudencialmente la alteración sobrevenida de las circunstancias y el grave perjuicio en relación a los acuerdos prematrimoniales.

37. En el caso de que dicha ley aplicable al acuerdo prematrimonial fuera el Derecho civil común español sería necesario tener en cuenta lo que a continuación se expone. Como ya se ha señalado al inicio del presente trabajo, los acuerdos prematrimoniales son prospectivos. Uno de los fines es regular aspectos relativos a las consecuencias económicas de un divorcio o separación antes de que la ruptura se produzca. El hecho de que los cónyuges se animen a realizar este tipo de acuerdos sólo puede valorarse como algo positivo. El momento de acordar tales previsiones es el idóneo, la predisposición de los cónyuges antes de celebrar el matrimonio a que este funcione son muy buenas. Sin embargo, a decir verdad, cuando se realizan este tipo de pactos, siempre puede haber (sobre todo cuando no se ha recibido un buen asesoramiento legal) dudas sobre todo para uno de los cónyuges de si lo previsto en el pacto puede verdaderamente ser vinculante en un futuro. Esta duda surge porque se puede llegar a pensar que lo que se conoce como "alteración sobrevenida de las circunstancias" pueda hacer que lo acordado nunca vaya a ser ejecutado. Pero a decir verdad es que ni el mejor asesoramiento ni las mejoras de las circunstancias puede asegurar con total seguridad que el acuerdo finalmente va a ser eficaz. Esto sucede sobre todo cuando transcurren muchos años entre la celebración del pacto y la ejecución del mismo.

38. Como ha sostenido previamente la doctrina civilista ${ }^{95}$, consideramos que el acuerdo prematrimonial debe regirse por el principio pacta sunt servanda y que la regla rebus sic stantibus debe interpretarse de forma restrictiva. Esta visión permite garantizar la seguridad jurídica. Así, aunque la revisión judicial no deja de ser una excepción al principio de pact sunt servanda es perfectamente comprensible que exista debido a que los acuerdos prematrimoniales no son meros contratos patrimoniales ${ }^{96}$. Cuando el juez analiza las circunstancias de los cónyuges al momento de ejecución del acuerdo, debe tener en cuenta los cambios imprevisibles, sobrevenidos o inesperados ${ }^{97}$. Estos cambios no han podido ser provocados por los cónyuges. Se debe tratar de una enfermedad seria, el nacimiento de un hijo con una enfermedad grave, la pérdida del trabajo o del negocio familiar, un accidente que deje secuelas, etc.. En nuestra opinión, el simple cambio de circunstancias no debería ser suficiente, ya que si así fuera la inseguridad jurídica en relación a la eficacia de este tipo de pactos sería total. Además de lo anterior, es necesario apreciar si en el caso concreto esos cambios provocan una situación perjudicial grave para los cónyuges. En definitiva, que se pueda apreciar injusticia para uno o ambos cónyuges con la ejecución del acuerdo prematrimonial.

Se podría decir que esa es la línea en la que va el art. 231.20 apartado 5 del Código Civil catalán un pacto prematrimonial que es gravemente perjudicial o injusto para uno de los cónyuges no debe desplegar efectos.

De una forma similar se entiende en ordenamientos extranjeros como el estadounidense donde se hace alusión a la "injusticia sustancial" (art. 7.05 ALI Principles) ${ }^{98}$. Lo difícil como ya ha señalado la doctrina es determinar qué debe entenderse por grave perjuicio ${ }^{99}$. En nuestra opinión, el concepto no puede ser excesivamente amplio, no puede tratarse de cualquier perjuicio o daño derivado del cambio

95 Vid. C. Martínez Escribano, Pactos prematrimoniales..., pp. 190;M. Medina Alcoz, "Pactos prematrimoniales, «pacta sunt servanda» y modificación sobrevenida de las circunstancias", en M. Pereña/P. Delgado Martín, Nuevas orientaciones del Derecho civil en Europa, Thomson Reuters Aranzadi, Cizur Menor (Navarra), 2015, p. 774; A . Rodriguez Guitián, Los pactos de Pre-Ruptura ..., p. 223.

96 Vid. también en este sentido, A. Rodriguez Guití́n, Los pactos de pre-Ruptura ..., p. 223.

97 Vid. L. Allueva Aznar, Prestación compensatoria y ..., pp. 309-310; A . Rodriguez Guitián, Los pactos de PreRuptura..., p. 235.

98 Para un mayor detalle vid. I. Mark Ellman, pp. 841-847.

99 A. Rodriguez Guitián, Los pactos de Pre-Ruptura ..., p. 238. 
de circunstancias. Debe tratarse de un daño de cierta entidad que en el caso concreto haga que el pacto prematrimonial carezca del fin por el que se formalizó. El problema de no entenderse así es que daría lugar a que la autonomía de la voluntad de los futuros cónyuges no serviría de mucho.

39. En nuestra opinión, consideramos que este análisis del acuerdo prematrimonial sobre la alteración sobrevenida de las circunstancias no puede realizarse sin tener en cuenta el contenido del acuerdo. Así, por tanto, en los siguientes epígrafes vamos a destacar cláusulas que en abstracto o en general se podrían incluir en el acuerdo prematrimonial pero que produciéndose un cambio sobrevenido de las circunstancias pueden plantear problemas de eficacia en el caso concreto. En particular vamos a estudiar: 1) las cláusulas en las que se renuncian a derechos futuros; 2) las cláusulas en las que se conceden derechos que por ley no se reconocen; 3) las cláusulas donde se recogen indemnizaciones a favor de los cónyuges por el incumplimiento de deberes durante el matrimonio.

B) Acuerdos con especial transcendencia al momento de la ejecución del acuerdo: cláusulas en los que se renuncian a derechos futuros y pactos en los que se atribuye una prestación patrimonial no reconocida por la ley

\section{a) La renuncia anticipada a la prestación compensatoria}

40. Desde un punto de vista internacional privatista, como ya se ha señalado, el instrumento legal internacional aplicable a la renuncia anticipada a la prestación compensatoria sería el PH 2007. Si resultara de aplicación el Derecho español, en atención al art. 97 CC se puede señalar que la pensión o prestación compensatoria tiene la finalidad de compensar económicamente al cónyuge que debido a la separación o al divorcio va a quedar en una situación de desventaja económica respecto del otro cónyuge ${ }^{100}$. Es una forma de equilibrar el patrimonio de un cónyuge que va a sufrir un empeoramiento respecto a la situación que tenía durante el matrimonio. El citado artículo es una norma de derecho dispositivo, ya que dispone que, en defecto de acuerdo entre los cónyuges, el juez deberá fijar su importe en atención a una serie de criterios que no son numerus clausus ${ }^{101}$. Así, lo ha considerado el Tribunal Supremo en su sentencia de 2 de diciembre de $1987^{102}$ y también así lo manifiesta en la sentencia que vamos a comentar posteriormente de 30 de mayo de $2018^{103}$. Este carácter dispositivo de la pensión compensatoria permite plantear si es posible renunciar a dicha compensación mediante pacto prenupcial. Tradicionalmente, la cuestión ha parecido más clara a favor de su renuncia si la misma se realizaba una vez que ha tenido lugar la ruptura ${ }^{104}$.

Sin embargo, no ha existido siempre una unanimidad en la doctrina ni en la jurisprudencia cuando tal renuncia se realizaba antes del matrimonio. Esto era así debido a que tal renuncia en un momento en el que las partes no conocían sus circunstancias futuras hacía desconfiar sobre su validez. De este modo, los tribunales españoles han sostenido posiciones a favor y en contra de la renuncia a la pensión compensatoria ${ }^{105}$. Actualmente, se puede decir que la opinión doctrinal mayoritaria descansa en que se-

100 Sobre el derecho de pensión compensatoria vid. ad ex., L. Allueva AznAR, Prestación compensatoria y autonomía privada familiar, Valencia, Tirant lo Blanch, 2016, pp. 43 y ss.

101 Las circunstancias que señala el art. $97 \mathrm{CC}$ que permiten al juez determinar la cuantía de la pensión compensatoria son: 1. ${ }^{a}$ Los acuerdos a que hubieran llegado los cónyuges; $2 .{ }^{a}$ La edad y el estado de salud;

3. ${ }^{a}$ La cualificación profesional y las probabilidades de acceso a un empleo; $4{ }^{a}$ La dedicación pasada y futura a la familia; $5{ }^{a}$ La colaboración con su trabajo en las actividades mercantiles, industriales o profesionales del otro cónyuge; $6 .{ }^{a}$ La duración del matrimonio y de la convivencia conyugal; $7 .{ }^{a}$ La pérdida eventual de un derecho de pensión; $8 .{ }^{a}$ El caudal y los medios económicos y las necesidades de uno y otro cónyuge; $9 .{ }^{a}$ Cualquier otra circunstancia relevante.

102 STS de 2 de diciembre de 1987 (RJ 1987\9174).

103 STS de 30 de mayo de 2018, n 1925/2018, ECLI:ES:TS:2018:1925.

104 Vid. A. L Rebolledo Varela, "Pactos en previsión...", pp. 737-738.

105 En contra $a d$ ex. SAP de Asturias de 12 de diciembre de 2000 (AC 2000/151) donde se señala la imposibilidad de renunciar a un derecho que todavía no ha surgido. A favor de la renuncia, vid. STS de 2 de diciembre de 1987 (RJ 1987\9174); STS de 20 de abril de 2012 (RJ 20125911);SAP Murcia de 29 de octubre de 2002 (JUR 2003/71008);SAP de Madrid, de 27 de noviembre de 2002 (JUR 2003/92086); SAP de A Coruña de 4 de abril de 2006 (JUR 2007\135060); SAP de Madrid, de 27 de febrero de 2007, FD 5º (JUR 2007\15141). 
ría válida una renuncia a la prestación compensatoria ${ }^{106}$. Los argumentos jurídicos que permiten apoyar la validez de la renuncia en un acuerdo prenupcial podrían descansar en:

1) Posibilidad de renunciar a derechos futuros. Hay autores que consideran que es posible renunciar a derechos futuros, puesto que el art. $1271 \mathrm{CC}$ permite que sean objeto de los contratos las cosas o derechos futuros, también es posible renunciar a ellos. La pensión compensatoria es un derecho dispositivo y se podría pactar su renuncia ${ }^{107}$. En el mismo sentido, de acuerdo al art. 6.2 CC es posible la exclusión voluntaria de la ley aplicable y renunciar a derechos cuando dichas renuncias no contravengan el interés o el orden público ni tampoco los derechos de terceros;

2) La renuncia a la pensión compensatoria no puede implicar en todo caso un vicio en el consentimiento por desconocimiento de las circunstancias futuras. El hecho de renunciar a un derecho que podría perjudicar a una de las partes por las circunstancias futuras imprevistas no implica que la parte no haya dado su consentimiento libremente y con la información suficiente. Es más, si el pacto prematrimonial es firmado ante notario, éste ya habrá advertido de la situación que podría tener lugar de darse tales circunstancias en el futuro y las implicaciones de la renuncia. Así, los tribunales han venido aceptando la renuncia a la pensión compensatoria en un acuerdo prematrimonial siempre que la renuncia sea recíproca y no atente contra el principio de igualdad ${ }^{108}$

3) Carácter indemnizatorio o resarcitorio de la pensión, no naturaleza alimenticio-asistencial ${ }^{109}$. Al considerarse un derecho disponible dirigido a paliar una situación de inferioridad económica en el momento de la ruptura, las partes son totalmente libres para hacer valer su derecho. Esta naturaleza hace que no esté justificada la intervención de los poderes públicos para modificar lo que las partes han considerado oportuno en ejercicio de la autonomía de la voluntad.

41. Por lo tanto, en definitiva, se podría decir que la renuncia a la pensión compensatoria podría ser totalmente admisible siempre y cuando sea recíproca y se salvaguarde el principio de igualdad. Esta necesidad de igualdad entre los cónyuges nos lleva a plantearnos si sería válida la renuncia aunque perjudique a uno de los cónyuges. Especialmente, en los supuestos en los que las circunstancias han cambiado de tal forma que dicho ejercicio de la autonomía de la voluntad perjudica gravemente a una de las partes. Cabría plantearse si en estos casos la renuncia carecería de validez, y si fuera así, a qué criterios se debe atender para considerar que las circunstancias no previstas perjudican a una de las partes. Diferentes sectores doctrinales y jurisprudenciales consideran que en los casos en los que las circunstancias han variado sustancialmente y de forma imprevisible quedando una de las partes perjudicada gravemente por dicha renuncia debería la misma no tenerse por válida ${ }^{110}$. Un perjuicio grave puede ser no contar

106 Vid. L. Allueva aznar, Prestación compensatoria y ..., pp. 209-214; M.P. García Rubio, "Los pactos prematrimoniales de..., ," p. 1662-1664:.T. MARÍN GARCÍA DE LEONARDO, Los acuerdos de los cónyuges en la pensión por separación y divorcio, Tirant lo Blanch, Valencia, 1995, pp. 66-71; M. Medina AlCoz, "Pactos prematrimoniales, <<pacta sunt servanda >> y modificación sobrevenida de las circunstancias", en M. Pereña/P. Delgado Martín, Nuevas orientaciones del Derecho civil en Europa, Thomson Reuters Aranzadi, Cizur Menor (Navarra), 2015, p.779; A. L Rebolledo Varela, "Pactos en previsión...", p. 750; A. Rodriguez GuITÍ́N, Los pactos de pre-Ruptura..., pp. 279-280. Resulta muy interesante aunque diferente a la de los autores anteriores la visión que plantea A. L. CABEZuelo ARENAS, “¿Es válida la renuncia a una eventual pensión compensatoria formulada años antes de la separación en capitulaciones matrimoniales?", Revista doctrinal Aranzadi Civil-Mercantil, nº 18/2004, pp. 1-12.

107 STS de 2 de diciembre de 1987 (RJ 1987\9174). Vid. también sobre la renunciabilidad a la pensión compensatoria J. Montero Aroca, El convenio regulador en la separación y en el divorcio: La aplicación práctica del art. 90 del Código Civil, Tirant lo Blanch, Madrid, 2002, pp. 194 y ss; L. Aguilar Ruiz/C. Hornero Méndez, "Los pactos conyugales de renuncia a la pensión compensatoria: autonomía de la voluntad y control judicial”, Revista Jurídica del Notariado, núm. 57, 2006, pp. 9 y ss.

108 STS de 2 de diciembre de 1987 (RJ 1987\9174); SAP Murcia de 29 de octubre de 2002 (JUR 2003/71008);SAP de Madrid, de 27 de noviembre de 2002 (JUR 2003/92086); SAP de A Coruña de 4 de abril de 2006 (JUR 2007\135060); SAP de Madrid, de 27 de febrero de 2007, FJ $5^{\circ}$ (JUR 2007\15141).

109 SAP de Ciudad Real, de 2 de diciembre de 2002, FJ $2^{\circ}$ (JUR 2003\32630).

110 SAP de Granada, de 14 de mayo de 2001 (AC 2001/1588). Vid. también en el mismo sentido, T. Marín García DE LEONARDO, Los acuerdos de los cónyuges en la pensión por separación y divorcio, Tirant lo Blanch, Valencia, 1995, pp. 70 y 71; A. L Rebolledo Varela, “pactos en previsión de...”, p. 753. 
con medios económicos suficientes como para poder subsistir, ad ex., por accidente que incapacite a uno de los cónyuges, por abandono carrera profesional por el cuidado del hogar y de los hijos, por pérdida de empleo o entrada en concurso de acreedores del cónyuge empresario. Esta visión no es compartida por la DGRN que considera que sólo hay que velar por los hijos y el derecho de alimentos, no por la pensión compensatoria de los cónyuges, ya que es perfectamente renunciable ${ }^{111}$. Por ese motivo, desde la DGRN se considera que los pactos de renuncia a la pensión compensatoria no requieren homologación judicial para la inscripción en el Registro.

42. Una cuestión a tener en cuenta es que la no validez de la renuncia en atención a circunstancias sobrevenidas que hacen que una de las partes sea gravemente perjudicada no obsta para que el resto del acuerdo prematrimonial sea válido.

43. Desde nuestro punto de vista, la inclusión de la renuncia a la pensión compensatoria en un acuerdo prematrimonial como regla general puede ser perfectamente válida. La libertad de pacto entre las partes prima cuando se trata de derechos disponibles. A nuestro entender si el pacto no atenta contra los hijos, la libertad de los cónyuges o su dignidad, no debería haber razón para que la renuncia no fuera eficaz. Ni si quiera entendemos que sea necesario que la renuncia sea recíproca. El hecho de que no sea una renuncia recíproca no debería entenderse per se como nula. Es necesario analizar el resto de cláusulas del acuerdo para poder tener una impresión general del mismo.

44. El inconveniente a la renuncia podría existir en los supuestos en los que las circunstancias hayan cambiado de forma tan considerable que perjudique gravemente a una de las partes. Este argumento jurídico podría basarse en la teoría de la base objetiva del negocio jurídico, según la cual la causa o base que se tuvo en cuenta para llevar a cabo la renuncia ha cambiado ${ }^{112}$. El problema de admitir esta excepción a la validez puede resultar un arma de doble filo, o mejor dicho, una vía para plantear la ineficacia de la renuncia en todo caso, ya que, si el pacto prematrimonial se firmó veinte años atrás es obvio que las circunstancias de los cónyuges habrán cambiado. Por lo tanto, será el caso concreto, teniendo en cuenta la admisibilidad general a la renuncia de la pensión compensatoria, el que verdaderamente podrá indicar a un tribunal si efectivamente las circunstancias son tan sobrevenidas o inesperadas como para que la renuncia no sea válida por perjudicar gravemente a una de las partes.

\section{b) La renuncia al uso de la vivienda familiar}

45. En cuanto a la renuncia al uso de la vivienda familiar es necesario tener presente que la vivienda familiar suele ser el bien con más valor del matrimonio, y en muchas ocasiones, sólo es el único bien del patrimonio familiar. Por ese motivo, generalmente es el bien sobre el que más disputas se concentran en los procesos de divorcio ${ }^{113}$. De la lectura del art. $96 \mathrm{CC}$ se puede extraer la conclusión de que serán las circunstancias que existan en el momento de la separación o divorcio las que determinarán en gran medida si lo pactado vía acuerdo prematrimonial va a poder mantener su validez. Cuando hablamos de circunstancias nos referimos, ad ex., a la existencia o no de hijos comunes, a qué progenitor se le asigna el cuidado de los hijos o a la situación económica de los cónyuges en ese momento.

46. De este modo, consideramos que aunque existan hijos, las previsiones relativas a la vivienda familiar pueden sobrevivir y desplegar su eficacia siempre que se procure el bienestar de los hijos. El interés del menor siempre va a estar antes que cualquier previsión que las partes hayan realizado en cualquier tipo de pacto. En nuestra opinión, los cónyuges con y sin hijos deberían disponer de la misma libertad para poder planificar el uso de la vivienda familiar en caso de ruptura. No obstante, no hay que olvidar que esa autonomía de los cónyuges, siempre va a ser supervisada por el juez para garantizar el

111 Resolución de 10 de noviembre de 1995(RJ 1995/8086); Resolución de 1 de septiembre de 1998 (RJ 1998/6593); Resolución de 19 de junio de 2003 (RJ 2003/6172).

112 SAP de Granada, de 14 de mayo de 2001 (AC 2001/1599), FJ 1².

113 Vid. C. Martínez Escribano, Pactos prematrimoniales..., p. 108. 
bienestar de los menores. Así, ad ex. con hijos menores una cláusula que limite temporalmente el uso de la vivienda familiar a los hijos y al cónyuge custodio es difícil que sea aprobada por un juez. Sin embargo, sin hijos menores comunes, si que es cierto que existe una mayor posibilidad de disponer sobre la vivienda familiar. Esto es así porque sin hijos el uso de la vivienda familiar es un derecho puramente patrimonial ${ }^{114}$. No obstante, no se puede olvidar que aún sin hijos y existiendo acuerdo al respecto, el juez puede modificar lo dispuesto por las partes en cuanto al uso de la vivienda familiar si el cónyuge al que le afecta la renuncia se encuentra en una situación precaria o de necesidad.

47. En definitiva, las cláusulas a incluir en un acuerdo prematrimonial sobre la vivienda familiar podrían ser muy variadas, ad ex., la venta del inmueble en un corto período de tiempo desde que el matrimonio se disuelve, o que el cónyuge que use la vivienda pague total o parcialmente al otro un alquiler en otra diferente, o la adjudicación de la propiedad a uno de los cónyuges en contraprestación de que ayude al otro a acceder a una nueva vivienda o la introducción del factor de culpabilidad en la ruptura para asignar el uso de la vivienda.

48. En el caso de que el matrimonio cuente con hijos mayores de edad la visión actual de los tribunales es diferente, aunque incluso todavía dependan económicamente de sus progenitores. Prueba de ello es un cambio de tendencia que se produjo con la STS de 5 de septiembre de $2011^{115}$, donde se dispone que sería posible que se extinguiera el uso a la vivienda familiar cuando los hijos alcancen la mayoría de edad aunque no dispongan todavía de independencia económica. A la luz de esta línea jurisprudencial del TS, hay doctrina que entiende que podrían ser válidos aquellos pactos preventivos donde los cónyuges acuerdan una limitación temporal del uso de la vivienda familiar que afecte a los hijos mayores de edad aunque todavía no sean independientes económicamente ${ }^{116}$.

\section{c) La reciente sentencia del TS de 30 de mayo de 2018}

\section{i. Hechos del caso}

49. La sentencia de 30 de mayo del Tribunal Supremo ${ }^{117}$ resulta de interés debido a que es el último (al menos que tengamos constancia de ello) asunto en el que el TS resuelve sobre la renuncia anticipada en un acuerdo prematrimonial a un posible derecho de prestación compensatoria y al derecho al uso de la vivienda familiar.

50. Los hechos del caso podrían quedar resumidos en lo siguiente: Don José Miguel, de profesión abogado y de nacionalidad española y Doña Gloria de nacionalidad rusa y diecinueve años más joven que él deciden contraer matrimonio en España en diciembre del año 2009. La pareja con sendos fracasos matrimoniales a sus espaldas, comienza a convivir en 2006, año en el que Doña Gloria viene a España acompañada de su hija. Antes del enlace, deciden firmar un acuerdo prematrimonial ante notario.

Básicamente, en el acuerdo se recoge que ambos renuncian de forma recíproca a cualquier indemnización y/o pensión compensatoria. Además el acuerdo señala que el domicilio conyugal se encuentra en Valencia, pero que Doña Gloria renuncia de forma expresa al uso o posesión del mismo debido a que es un bien privativo del futuro esposo. No obstante, el acuerdo también recoge que el marido si fuera procedente le atribuirá el uso con el respectivo alquiler de una vivienda adecuada en el caso de que existieran hijos comunes y se le atribuyera a Doña Gloria la custodia sobre los mismos. Además, el acuerdo también plasma la voluntad del futuro cónyuge de cambiar su testamento. El fin es otorgarle a su futura esposa el tercio de libre disposición y otorgarle el usufructo de determinados bienes.

\footnotetext{
114 M. Medina Alcoz, "Pactos prematrimoniales, <<pacta..., p. 783.

115 STS de 5 de septiembre de 2011 (RJ 2011/5677). La visión mantenida en esta sentencia se ha seguido en posteriores resoluciones del TS, tales como la de 11 de noviembre de 2013 (RJ 2013/20694) o la de 6 de octubre de 2016

116 A. Rodriguez Guitián, Los pactos de Pre-Ruptura ..., p. 306.

117 STS de 30 de mayo de 2018, nº 1925/2018, ECLI:ES:TS:2018:1925.
} 


\section{ii. Recorrido judicial del asunto}

51. Tras siete años de matrimonio y sin hijos comunes, la pareja decide poner fin a su relación. Doña Gloria es la que interpone demanda de divorcio en enero de 2016. Dicha sentencia es dictada por el Juzgado de Violencia sobre la Mujer $n^{\circ} 4$ de Valencia pocos meses después mediante la cual no sólo se dicta el divorcio, se le atribuyen 400 euros de pensión al mes durante dos años a la esposa y también se le conceden 3000 euros de litis expensas.

52. En primera instancia, el juez considera que la renuncia que realiza la esposa en el pacto prematrimonial a la pensión compensatoria es nula. Esta nulidad no es porque en el momento de la firma del acuerdo existiera vicio alguno en el consentimiento, sino tal nulidad es por atentar contra el derecho a la igualdad. Así lo considera el Juzgado de Violencia sobre la mujer debido a la precariedad económica de la demandante al momento de ejecución del pacto.

53. El exesposo recurre la decisión, entiende que el pacto prematrimonial firmado por ambos ante notario siete años atrás es perfectamente válido, y por tanto, vinculante, lo que implicaría ninguna obligación económica para con su exesposa. Ésta, sin embargo, argumenta que el acuerdo prematrimonial lo firmó sin ser consciente de sus implicaciones y sin tener conocimiento del idioma español, encontrándose en una situación de precariedad.

La Audiencia provincial de Valencia apoya la tesis del marido ${ }^{118}$. De la sentencia de la Audiencia se podrían extraer tres razonamientos en los que se apoya el tribunal para dar validez al acuerdo prematrimonial: 1)los acuerdos prematrimoniales son negocios jurídicos perfectamente admitidos en el ordenamiento jurídico español; 2) el derecho a la pensión compensatoria es un derecho disponible por los futuros cónyuges. Así, éstos en base a la autonomía de la voluntad pueden renunciar a él o configurarlo como deseen en atención a sus circunstancias; 3) los acuerdos prematrimoniales como negocios jurídicos del derecho de familia pueden encontrar límites que persiguen proteger la igualdad de los cónyuges y la protección del menor. En este caso, al no existir menores que proteger, el tribunal tuvo que analizar si la igualdad entre los cónyuges se menoscaba por la renuncia a la pensión compensatoria. La Audiencia Provincial considera que debido a las circunstancias personales de los cónyuges (su edad, profesión y experiencias maritales previas) junto con el tipo de pacto (regulación exclusiva de efectos económicos) y la inexistencia de hijos comunes que no se podía considerar menoscabado el derecho a la igualdad ${ }^{119}$. Es más, el propio tribunal enfatiza en que ambos tenían plenamente consciencia del documento que firmaban, de su transcendencia y alcance por lo que no darle plena validez al mismo sería quebrantar la libertad de pacto y la seguridad jurídica.

\section{iii. La decisión del Tribunal Supremo}

54. El Tribunal Supremo en su sentencia de 30 de mayo de 2018 sigue lo dispuesto por la Audiencia Provincial de Valencia. Básicamente el TS para analizar el acuerdo prematrimonial lo que hace es estudiar diferentes aspectos de las circunstancias de los cónyuges, la forma y contenido del acuerdo prematrimonial para llegar a la misma conclusión que la Audiencia Provincial.

55. El primer análisis que realiza el TS sobre el acuerdo prematrimonial son las circunstancias de los futuros cónyuges al momento de la firma del acuerdo. Aspectos tales como ambos había estados casados previamente, que el acuerdo se había firmado ante notario, que la esposa conocía el idioma castellano hacen considerar al tribunal que Doña Gloria conocía lo que estaba firmando y la transcendencia que implicaba ${ }^{120}$.

\footnotetext{
118 SAP de Valencia de 6 de abril de 2017, nº 325/ 2017, ECLI:ES:APV:2017:1323.

119 SAP de Valencia de 6 de abril de 2017, nº 325/ 2017, ECLI:ES:APV:2017:1323, FJ $7^{\circ}$.

120 STS de 30 de mayo de 2018, n$^{\circ}$ 1925/2018, ECLI:ES:TS:2018:1925, FJ 5².
} 
56. El segundo análisis versa sobre la vulneración del orden público ${ }^{121}$. El TS vuelve a valorar aspectos como la edad de la mujer, su formación y la inexistencia de hijos en común. El TS valora circunstancias en el momento de la firma del pacto y también en el momento de la ejecución del mismo. Para el alto Tribunal, al momento de la firma del acuerdo, la mujer entendía lo que firmaba por tener conocimiento del idioma español. En el momento de la ejecución del acuerdo, considera que la esposa tiene capacidad de poder generar ingresos económicos tras el divorcio por lo que no ve procedente conceder una pensión compensatoria.

Es interesante destacar la última afirmación con la que cierra el razonamiento de que el pacto no menoscaba el orden público, señalando "estos elementos de juicio permiten inferir que cuando se firmaron los pactos prematrimoniales no se sometió a Doña Gloria a una situación de previsible precariedad" 122 . A nuestro juicio, esta frase final es relevante porque no deja de ser un análisis como el de la second look doctrine estadounidense ${ }^{123}$. Aunque no se puede leer claramente en la sentencia, el TS realiza un análisis de las circunstancias en el momento de la firma del acuerdo y en el momento de la ejecución. La experiencia de ambos, su edad y la posibilidad de trabajar de la esposa tanto antes como después del matrimonio le hacen llegar a la conclusión de que no ha habido un cambio de circunstancias tal que haga que lo previsto años atrás en el acuerdo prematrimonial la deje en una situación injusta o en palabras del TS "de precariedad".

57. El último razonamiento o análisis del TS descansa en comprobar si el acuerdo prematrimonial menoscaba el derecho de igualdad, la libertad o la dignidad de la esposa ${ }^{124}$. El Tribunal considera que el mero hecho de firmar un acuerdo prematrimonial no puede entenderse como un sometimiento al esposo. Para el TS es reflejo de una relación entre iguales basada en la confianza. Además, el Tribunal destaca circunstancias del caso concreto que son importantes a su juicio para apreciar la falta de desigualdad tales como que el acuerdo prematrimonial en determinados aspectos beneficia a la esposa. Esto es así porque se acoge a su hija, aunque no lo señala expresamente el TS, en el acuerdo también se establece que se le reconoce un tercio de libre disposición en el testamento de su futuro marido y que el marido le permite adoptar los apellidos de éste. Es interesante esta valoración en conjunto que realiza el TS. Es cierto que la cláusula de la renuncia a la pensión compensatoria o al uso a la vivienda familiar podría ser perjudicial para la esposa pero hay otras disposiciones del acuerdo que le pueden resultar favorables. Estos argumentos hacen considerar al TS que el acuerdo prematrimonial es completamente válido y que impide que Doña Gloria tenga derecho a una pensión compensatoria.

\section{d) Pactos en los que se atribuye una prestación patrimonial no exigida por la ley}

58. En concreto, en este epígrafe vamos a tratar un tipo concreto de acuerdos: aquellos en los que se crea una renta vitalicia. Esto no quiere decir que no puedan existir otros con un fin similar, como puede ser el acuerdo prematrimonial en el que se incluye el pago de una mejora económica o un pago voluntario de alimentos. Todos estos tienen un aspecto en común, no excluyen derechos que la ley concede a los cónyuges sino que se trata de pactos a título gratuito, de una liberalidad de uno de los cónyuges frente al otro, mediante la cual se atribuye un derecho que la ley no contempla.

59. En particular, en relación a la concesión de una renta vitalicia en un acuerdo prematrimonial se podrían destacar dos características:

1) No reciprocidad. Esa prestación que se reconoce puede ser sólo a favor de uno de los cónyuges. Esta unilateralidad no lesionaría el derecho de igualdad de los cónyuges.

2) Creación de un derecho ex novo no contemplado por la ley. El acuerdo prematrimonial es la vía que uno o ambos cónyuges utilizan para atribuir al otro un derecho que la ley no contem-

\footnotetext{
121 STS de 30 de mayo de 2018, $\mathrm{n}^{\circ}$ 1925/2018, ECLI:ES:TS:2018:1925, FJ 6º.

122 STS de 30 de mayo de 2018, $n^{\circ}$ 1925/2018, ECLI:ES:TS:2018:1925, FD $6^{\circ}$.

123 Vid. I. Mark Ellman, "Marital Agreements and Private Autonomy in the United State”, en J.M Sherpe, Marital Agreements and Private Autonomy in comparative perspective, Hart Publishing, Oregon, 2012, pp. 427-429.

124 STS de 30 de mayo de 2018, nº 1925/2018, ECLI:ES:TS:2018:1925, FD $7^{\circ}$.
} 
pla. No es una prestación que se concibe para sustituir a otra que podría surgir por ley como ad ex, la prestación por desequilibrio del art. 97 CC. Es decir, no se recoge una renta vitalicia para sustituir a una prestación por desequilibrio. En el caso de que así fuera, no estaríamos en puridad ante un pacto que atribuye derechos ${ }^{125}$.

60. La validez de este tipo de cláusulas descansa básicamente en los mismos criterios que ya hemos estudiado anteriormente en el presente trabajo. A juicio del TS español, es necesario que se respeten los arts. $1255 \mathrm{CC}$ y $1261 \mathrm{CC}^{126}$ y también el art. $90.2 \mathrm{CC}^{127}$. Es interesante la crítica que hace la doctrina a que el TS aplique a los acuerdos prematrimoniales en los que se prevé una renta vitalicia un precepto (el art. 90.2 CC) relativo al convenio regulador, cuando se trata de pactos que no comparten el mismo fin ${ }^{128}$. Además de lo anterior, para comprobar la validez de estos acuerdos es necesario tener en cuenta los arts. 618 a 656 CC previstos para la donación. En particular, la doctrina ha considerado relevante tener en cuenta que en el acuerdo prematrimonial no se va a poder hacer disposiciones que no permitan al donante reservarse lo necesario para vivir en un estado correspondiente a sus circunstancias (art. $634 \mathrm{CC}$ ) o dar o recibir por donación más de lo que se puede dar o recibir por testamento $(\operatorname{art} .636 \mathrm{CC})^{129}$.

61. El problema de este tipo de acuerdos no reside tanto en su validez, que en principio no plantearía ningún problema sino en el caso de revisión judicial. En este caso, es importante tener en cuenta que a diferencia de los acuerdos donde se excluyen derechos, donde quizás los jueces se pueden mostrar más precavidos a analizar las circunstancias de los cónyuges, el derecho de igualdad y demás. En este tipo de pactos donde se realicen liberalidades hay que tener en cuenta que no van a declarar ineficaces tan fácilmente. Prueba de ellos son las dos sentencias del TS que ya hemos señalado (STS de 30 de marzo de 2011 y de 24 de junio de 2015). En nuestra opinión, salvo un vicio en el consentimiento, es poco probable que estos pactos se declaren ineficaces cuando el cónyuge que hizo la liberalidad tiene patrimonio suficiente para poder realizarla. Por ese motivo, consideramos importante ser precavidos a la hora de prestar asesoramiento sobre este tipo de pactos. Es necesario advertir muy bien al cliente de que si en el momento de la ejecución cuenta con bienes para poder hacer frente a esa prestación a la que se comprometió vía acuerdo prematrimonial con mucha probabilidad va a ser considerada válida, ya que se recoge en un contrato. El hecho de que la relación se haya roto y lo que menos desee ese cónyuge es pagar una prestación a su exesposo o exesposa que no le corresponde por ley no es relevante para apreciar la validez de este tipo de cláusulas.

\section{e) Pactos indemnizatorios}

62. Un acuerdo prematrimonial podría dar cabida a priori como ya se ha señalado a todo tipo de pacto. Estas indemnizaciones podrían fijarse para paliar incumplimientos sobre aspectos patrimoniales o personales impuestos durante el matrimonio o indemnizaciones en el caso de que se produzca la ruptura.

63. En relación a las primeras, una indemnización a destacar sería la que se acuerda por extinción del régimen económico matrimonial. Se fija una cantidad generalmente dineraria a pagar a uno de

125 Vid. A Rodriguez Guitián, Los pactos de Pre-Ruptura..., p. 322.

126 Así lo recoge la STS de 31 de marzo de 2011 (RJ 2011/3137), FJ $3^{\circ}$ y $4^{\circ}$.

127 STS de 24 de junio de 2015, (RJ 2015/2657), ECLI: ES:TS:2015:2828, FJ 5º Esta sentencia es realmente importante porque supone la admisión sin ningún atisbo de dudas de la figura de los acuerdos prematrimoniales en el ordenamiento jurídico español. Comentarios de esta sentencia vid $\mathrm{M}^{\mathrm{a}} \mathrm{D}$. Cervilla Garzón, "Reflexiones en torno a los acuerdos prematrimoniales con previsiones de ruptura en nuestro derecho actual. A propósito de la Sentencia del TS de 24 de junio de 2015 ", C. LASARTE/ Ma .D. Cervilla, Ordenación económica del matrimonio y de la crisis de pareja, Tirant lo Blanch, Valencia, 2018, pp. 329-383; F.J. Colao Marín, Los acuerdos prematrimoniales..., pp. 78-86;M.S. Quicios MolinA, "Pacto prematrimonial de constitución de renta vitalicia a favor de la esposa. Comentario a la sentencia Tribunal Supremo de 24 de junio de 2015 (RJA 2015 ), 2657 ", Revista Cuadernos Civitas de Jurisprudencia Civil, Mayo-Agosto 2016.

128 Ma D. Cervilla Garzón, "Reflexiones en torno...", p. 343.

129 M.S. Quicios Molina, "Pacto prematrimonial de...”, p. 8; A Rodriguez Guití́n, Los pactos de pre-Ruptura..., p. 323. 
los cónyuges en el caso de extinción de régimen económico matrimonial ${ }^{130}$. Del mismo modo, también es posible recoger una cláusula donde se renuncie a la indemnización por extinción del régimen económico matrimonial ${ }^{131}$. Estos pactos indemnizatorios se encuentran como límite los derechos fundamentales y los principios esenciales sobre los que se sustenta la institución del matrimonio ${ }^{132}$.

64. En relación a las indemnizaciones que persiguen penalizar la solicitud de separación o del divorcio decir que la doctrina se encuentra dividida en cuanto a si deben ser consideradas válidas ${ }^{133}$. Los tribunales por su parte no se han considerado muy favorables a aceptar estas cláusulas en la que se obliga a quien solicite el divorcio a pagar al otro una indemnización, puesto que atentaría contra el derecho a divorciarse lo cual atentaría contra el orden público ${ }^{134}$. En nuestra opinión, huyendo del argumento paternalista, si esa indemnización no es excesivamente elevada, se debería considerar válida ${ }^{135}$. La realidad es que el derecho a divorciarse no quedaría extinguido o anulado realmente, sino lo que consigue con este tipo de cláusulas es restringirlo. Y consideramos que esta restricción podría ser plausible siempre teniendo en consideración el acuerdo prematrimonial en concreto y que no implique una supresión total de poder acceder al divorcio.

A nuestro juicio, la valoración que debe realizar el juez es si dos adultos de forma libre y voluntaria han querido fijar tal indemnización y hasta qué punto verdaderamente implica una restricción de su derecho a divorciarse o su derecho al libre desarrollo de la personalidad. Este tipo de indemnizaciones son una forma de hacer conscientes a los cónyuges que salirse del matrimonio tiene unos costes. En la sociedad actual, donde existe el divorcio sin causa quizás no se tiene plena consciencia sobre los costes o repercursión que la ruptura implica. Estos "costes" son emocionales y económicos, y no sólo "los pagan" los cónyuges también los hijos, demás familiares próximos e incluso terceros como puede ser el Estado o los acreedores de alguno de los cónyuges.

El hecho de que los cónyuges penalicen de forma razonable el acceder al divorcio fijando una indemnización no debería analizarse desde la perspectiva del daño que puede provocar a su derecho al divorcio, sino como un ejercicio pleno de la autonomía de la voluntad donde uno de los fines puede ser reforzar la situación económica en la que queda uno de los cónyuges tras el divorcio ${ }^{136}$. Este tipo de cláusulas pueden ser útiles en matrimonios jóvenes, donde normalmente la mujer renuncia a desarrollar su carrera profesional, se dedica al cuidado de los hijos y del hogar y posteriormente tras varias décadas de matrimonio, el marido es el que insta el divorcio. A nuestro juicio la libertad de acceder al divorcio

130 SAP de Álava, de 25 de abril de 2002.

131 SAP de Murcia,de 29 de octubre de 2002 (JUR 2003/71008)

132 Vid. A. J. Pérez Martín, Pactos prematrimoniales. Capitulaciones..., p. 92.

133 Opiniones no favorables a la validez de este tipo de cláusulas vid. ad. ex. F.J. Colao Marín, Los acuerdos prematrimoniales..., p. 165;I. PAZ AREs, "Previsiones capitulares", Recientes modificaciones legislativas para abogados de familia: Modificaciones fiscales, el síndrome de alienación parental y previsiones capitulares, Homenaje a Luis Zarraluqui, Asociación Española de Abogados de Familia, Dykinson, 2008,p. 140. C. Pinto ANDrade, Pactos matrimoniales en ..., p. 470-473; L. Rebolledo Varela,"Pactos en previsión de....” p. 748. Para opiniones favorables vid. ad ex. de las más actuales, A RodrigueZ Guitián, Los pactos de pre-Ruptura ..., p. 343.

134 En este sentido lo entendió la AP de Almería, de 17 de febrero de 2003 (AC 2003\623), FJ 2 ${ }^{\circ}$. Esta sentencia consideró nula una cláusula recogida en un acuerdo prematrimonial entre español y rusa donde se obligaba al marido a pagar a la esposa por cada día de matrimonio una cantidad dineraria en el caso de que la ruptura tuviera lugar. La AP consideró que esta cláusula que establecía la indemnización era realmente una cláusula penal. Su fijación implicaba penalizar el cese de convivencia lo cual va en contra del orden público matrimonial por considerarlo contrario a la moral, las buenas costumbres y la ética social. Por tanto, nula de acuerdo al art. 1328 CC. Para un mayor detalle sobre este tipo de cláusula vid. L. Martínez VÁzQuez de Castro, "Pactos prematrimoniales, cláusulas penales y daños morales", en Estudios Jurídicos en Homenaje al Profesor José María Miquel, Aranzadi, 2014, pp. 1863-1874.

135 Vid. A Rodriguez Guitián, Los pactos de pre-Ruptura ..., p. 343.

136 Cuando estamos pensando en este tipo de cláusulas que pueden limitar el acceso al divorcio no tenemos en mente que dichas cláusulas puedan plantear el mismo escenario que los covenant marriage o matrimonios blindados. Estos son unos tipos concretos de matrimonio. Existen en los Estados de Lousiana, Arkansas y Arizona donde se tiene que recibir asesoramiento especial antes de contraerlo para que los cónyuges conozcan sus implicaciones. En términos generales cuando se accede al matrimonio mediante un covenant marriage no es posible acceder al divorcio sin causa. Sólo es posible divorciarse si concurren causas graves como el adulterio o los malos tratos. Se han defendido como una forma de fortalecer la familia. Sin embargo, no tenemos del todo claro que así sea, prueba de ello es que son muy poco utilizados. La doctrina española se ha referido a los covenant marriage en F.J. ColaO MARÍN, Los acuerdos prematrimoniales..., p. 165-166; S. GASPAR LERA, “Acuerdos prematrimoniales sobre...”"1053 y 1054. 
no se anula, puede seguir solicitando el divorcio sin que exista causa alguna. Este derecho que se recoge en nuestro ordenamiento jurídico desde el año 2005 sigue existiendo. Sin embargo, eso no quiere decir que sea nula por atentar contra el orden público una cláusula donde el acceso al divorcio le va a suponer pagar una indemnización al otro cónyuge.

\section{Consideraciones finales}

65. Los acuerdos prematrimoniales en previsión de ruptura matrimonial son acuerdos complejos. Como se ha podido estudiar, esa complejidad se deriva básicamente por: 1) la relación afectiva de las partes; 2) su ejecución puede tener lugar muchos años después de su otorgamiento; 3) la previsión de situaciones que no se han producido. Puede que algún día se necesiten o puede que no. A nuestro juicio este último no debería ser un elemento importante en cuanto a la formación del consentimiento. Los asesores deben concienciar a los futuros cónyuges que lo recogido en un acuerdo prematrimonial es vinculante, al menos en el ordenamiento jurídico español lo es. Esto es así porque los acuerdos prematrimoniales son contratos, con requisitos que van más allá de los generales aplicables a los contratos sí, pero no dejan de ser obligatorios. Estos pactos son un reflejo de la autonomía de la voluntad entre cónyuges más que admitida en el ordenamiento español de igual forma que en el resto de ordenamientos europeos y anglosajones.

66. Por ese motivo, consideramos que lo esencial en relación a este tipo de acuerdos es estar informado, recibir un asesoramiento adecuado, que permita, en atención a lo expuesto en el presente trabajo tomar la decisión más informada y reflexionada posible. A nuestro juicio, poder probar que en esa primera fase que el acuerdo se formalizó en atención a todas las recomendaciones o criterios que hemos señalado es clave para que el acuerdo sea considerado eficaz. Esto es así porque, la segunda fase de análisis, requiere, como se ha estudiado, probar un cambio de circunstancias sobrevenidas cuyos perjuicios sean tan graves que hagan entender al juez que el acuerdo haya perdido toda su razón de ser. La prueba de esta segunda fase es más complicada, por lo que si no se pueden probar esas circunstancias tan excepcionales, el acuerdo se va a considerar válido y con posibilidad de desplegar plenos efectos. 